\title{
Isolation, Cultivation and Characterization of Flexibacteria
}

\author{
By R. A. LEWIN AND DORCAS M. LOUNSBERY \\ Scripps Institution of Oceanography, University of California, \\ San Diego, La Jolla, California 92038, U.S.A.
}

(Accepted for publication 4 June 1969)

\begin{abstract}
SUMMAR Y
Eighty-five strains of aerobic microbes capable of gliding on solid substrata have been isolated from samples of marine and freshwater mud and sand collected in various localities around the world. Each strain has been characterized in about 40 tests by a number of morphological, nutritional, physiological and biochemical features.
\end{abstract}

\section{INTRODUCTION}

This is one of a series of papers on the general subject of the flexibacteria*, a group of common but generally neglected micro-organisms (see Soriano \& Lewin, 1965). They are characterized by flexuous filaments, ranging from approximately $5 \mu \mathrm{m}$. to an indefinite length and approximately 0.5 to $\mathrm{I} \mu \mathrm{m}$. in width. They are capable of gliding on solid substrata, and thus are usually recognizable by the fimbriate margins of their colonies on agar. Members of this group can be distinguished from eubacteria by the relative flexibility of the cell walls, and by the absence of flagella and of endospores. They are apparently all Gram-negative. The flexibacteria are distinguishable from the filamentous blue-green algae-photosynthetic prokaryonts which they resemble in many ways-by the absence of chlorophyll and of phycobilin pigments. All strains of flexibacteria so far studied are heterotrophic. They are not, however, colourless: all of our strains, when grown in mass, can be seen to have a pink, orange, or yellow coloration attributable to the presence of one or more carotenoids.

Their taxonomy has, hitherto, been very unsatisfactory. In an attempt to remedy this in some measure, we collected a number of such gliding microbes, all aerobes, and studied their form, pigmentation, and other physiological and biochemical features in pure laboratory cultures. Our data are presented in this paper, summarized in Tables 2 to 6.

Mandel \& Lewin (1969) obtained GC values (molar percentages of guanine+ cytosine) for deoxyribonucleic acids extracted from these organisms. Their data, together with those presented in this paper, have been used by Fager (1969) for a recurrent group analysis, on the basis of which a classification of these gliding microbes has been proposed (Lewin, $1969 b$ ). The data have been independently evaluated by Colwell (1969), who reaches somewhat different taxonomic conclusions.

* These five papers on flexibacteria are published simultaneously. Nomenclature is dealt with in the paper by Lewin (1969) and all questions of priority in regard to names refer to that paper.

Vol. 58, No. I, was issued 25 November 1969 


\section{Origin and isolation of strains}

Eighty-five strains were studied, of which 62 came from marine shores and 23 from freshwater habitats; ten were pure cultures kindly made available by various colleagues; the rest were isolated in this laboratory, or in the Department of Microbiology, University of Costa Rica, without prior enrichment, in order to decrease the selectivity of the media employed.

Thirty-five of the strains were isolated from samplings of nearby streams, ponds, hot springs, and various marine shores, usually streaked on agar within a few hours of collection when this was possible. Fifty other strains were isolated from samples of wet littoral mud or sand from seashores around the world, forwarded to us in small polyethylene bags by colleagues (see Table I and Acknowledgements). Most of the samples were received within 3 to 7 days of their dispatch. Upon receipt, the contents of each package were emptied into $5 \mathrm{ml}$. of sterile sea water in a capped test-tube, left for 2 to 4 days in dim (room) light at room temperatures $\left(c .24^{\circ}\right)$, and then shaken and streaked on I \% agar medium containing $0.02 \%$ Tryptone. To suppress the growth and spreading of amoebae, myxomycetes and diatoms, Actidione (Upjohn Company, Kalamazoo, Michigan; I00 mg./1.) was usually incorporated into the media used for first plating, after it had been established that this concentration had no apparent inhibitory effect on any of the 30 flexibacterial strains then in our culture collection. (Use of this agent was suggested by the work of Zehnder \& Hughes (I958), who indicated that it is much less inhibitory to Cyanophyta than to eukaryotic algae.) Plates were examined after 3 or 4 days, and every 2 or 3 days thereafter for 2 or 3 weeks. Organisms producing spreading colonies or showing other indications of gliding movement (Lautrop, I965-67) were isolated by repeated streaking, usually from the margin of each colony, until a pure culture was obtained. (Colonies of this form have been well illustrated by Carlson \& Pacha (I968), who regarded such organisms as myxobacteria). The isolation procedure was described in detail by Lewin (1965 $b$ ). No precautions were taken to exclude, or on the other hand to supplement, the ambient light of the laboratories in which the isolations and characterization tests were made. Living cells from the colony margins were examined by phase-contrast microscopy at high magnification $(\times 400)$. Only gliding microbes were selected and isolated in this way: all flagellate bacteria were rejected.

From many samples of mud, sand, or littoral debris we were unable to isolate any gliding microbe, probably in part because of adverse conditions of temperature and aeration during the postal journey. From some we isolated one or more. As far as possible we tried to avoid isolating duplicates from any one source. Many strains, detected on the original streaked plates, were lost before they could be isolated. Others died before we could develop a suitable medium and regime for maintaining them in culture; some were lost on the journey from Costa Rica to La Jolla. Certain strains were isolated too late to be conveniently subjected to some of the diagnostic tests; hence data on them are incomplete. However, we included for study as many of our isolates as we had available, and excluded only the single sporulating form mentioned below, and a few fastidious strains of Saprospira albida and S. flammula which proved too delicate for routine handling with the others (see Lewin, 1965a). The origins of all strains tested are listed in Table I, on p. I58. 


\section{METHODS}

After a considerable amount of preliminary experimentation, the following two media $(I, 2)$ were generally found to be most satisfactory for the maintenance of marine and freshwater cultures respectively.

Medium I (for marine stock cultures). Filtered sea water, I000 ml.; $\mathrm{KNO}_{3}, 0.5 \mathrm{~g}$.; $\mathrm{Na}$ glycerophosphate, $\mathrm{O}^{\mathrm{I}} \mathrm{g}$.; trace-element solution, I.0 ml.; tris buffer (Sigma), I. ․ g.; Bacto-Tryptone (Difco), 5.0 g.; Bacto-Yeast Extract (Difco), 5.0 g.; adjusted to approximately $\mathrm{pH} 7.0$ agar, if required, I0.0 g.

Medium 2 (for freshwater stock cultures). Distilled water, $1000 \mathrm{ml}$; $\mathrm{MgSO}_{4} \cdot 7 \mathrm{H}_{2} \mathrm{O}$, ०.I g.; $\mathrm{KNO}_{3}$, O.I g.; $\mathrm{CaCl}_{2} .2 \mathrm{H}_{2} \mathrm{O}$, O.I g.; Na glycerophosphate, 0.I g.; trace-element solution, $\mathrm{I} \cdot 0 \mathrm{ml}$; ; tris buffer (Sigma), $\mathrm{I} \cdot 0 \mathrm{~g}$.; thiamine, $\mathrm{I} \cdot 0 \mathrm{mg}$.; cobalamin, $\mathrm{r} \cdot 0 \mu \mathrm{g}$; casamino acids (Difco), I $\bullet$ g.; glucose (added aseptically after autoclaving), $\mathrm{I} \cdot \circ \mathrm{g}$.; adjusted to approximately $\mathrm{pH} 7.5 \mathrm{agar}$, if required, $10.0 \mathrm{~g}$.

Filtered sea water could be replaced by a commercial sea-water substitute, such as 'Rila mix' (Utility Chemical Co., Paterson, New Jersey) or by a mixture of the following salts (g./1.): $\mathrm{NaCl}, 25 \cdot 0 ; \mathrm{MgSO}_{4} \cdot 7 \mathrm{H}_{2} \mathrm{O}, 5.0 ; \mathrm{CaCl}_{2} \cdot 2 \mathrm{H}_{2} \mathrm{O}, \mathrm{I} \cdot 0 ; \mathrm{KCl}, \mathrm{I} \cdot 0$. The following trace-element solution was found satisfactory: soluble salts of $\mathrm{B}, \mathrm{Fe}, \mathrm{Mn}$-each (as element) $0.5 \mathrm{mg}$. $/ \mathrm{ml}$.; soluble salts of $\mathrm{Co}, \mathrm{Cu}, \mathrm{Mo}, \mathrm{Zn}$ - each (as element) $0.0 \mathrm{I} \mathrm{mg.} / \mathrm{ml}$. Final concentrations of each element in the nutrient media were thus 0.5 and $0.01 \mathrm{mg} . / \mathrm{l}$.

In these media, growth rates and yields were satisfactory, and cultures retained viable cells for at least 2 or 3 weeks. Stock cultures, both in liquid media and on agar slants, were grown and kept at room temperatures. Higher temperatures (e.g. $30^{\circ}$ or $35^{\circ}$ ) often promoted more rapid growth, but also caused earlier death and lysis, to which flexibacteria seem generally prone. Our cultures were maintained alive by weekly transfers incubated at room temperature, in medium I (for marine strains) or 2 (for freshwater strains). Since living cells of certain strains, at least, may be recovered after lyophilization, one set of cultures was lyophilized in the American Type Culture Collection, and another set was frozen in liquid nitrogen; see Sanfilippo \& Lewin (1969).

Nutrition was studied in experiments as described by Lewin (1965b). Test-tubes, containing $3 \mathrm{ml}$. of medium, were supported in slanted racks gently shaken at about 75 oscillations $/ \mathrm{min}$. at an amplitude of $4 \mathrm{~cm}$. Experimental cultures were ordinarily incubated in a thermostatic room at $30^{\circ}$. The nutrition of two strains (CR-I 24 and PSY), which initially did not grow at this temperature, was studied at $25^{\circ}$. Other incubation temperatures were used in certain experiments, as indicated below.

Details of various other discriminatory tests follow. In tests 5 to IO, I2, I9, 20 and 22, the media were inoculated by applying a droplet of suspension to the surface; in II and 13 to 15 , they were inoculated by stabbing. They were incubated at $30^{\circ}$ unless otherwise specified (as in tests I to 3, 8, II, I7, I8 and 2I). Results from tests 27 to 3I were not used in the evaluation of relationships, since they could not be easily interpreted or regularly reproduced, or since they seemed to reveal no distinctions of taxonomic value because all our strains behaved similarly.

I. $G C$ value. Mole percentage of guanine+cytosine in the deoxyribonucleic acid. (See Mandel \& Lewin, 1969.)

2. Morphological examination. Cultures were grown in liquid without shaking, and were examined approximately $48 \mathrm{hr}$ after inoculation while still in or near the 
exponential phase of growth. Morphology was generally studied with a Wild phasecontrast microscope at magnifications of 600 or 800 diameters.

No attempt was made to confirm the absence of flagella by specific staining techniques. However, no swimming forms have ever been seen by phase-contrast microscopy of wet mounts of any gliding microbe in this study.

3. Electron-microscope examination of lysates. Two-day-old cultures of each strain were examined by Dr R. E. Reichle for the presence of rhapidosomes (Lewin, 1963), using a simplified form of the procedure described by Reichle \& Lewin (1968).

4. Pigmentation. Organisms were generally grown in darkness either in Petri plates on $2 \%$ agar medium (I or 2 as appropriate) and collected at the peak of growth by scraping, or in shaken flasks of liquid medium and harvested by centrifugation. Pigments were extracted in ethanol at $-20^{\circ}$ under nitrogen, in darkness, for at least $24 \mathrm{hr}$. Extracts were filtered through 'celite' (diatomite) on sintered glass filters. After evaporation of the ethanol in a slow current of nitrogen over a warm bath (approximately $50^{\circ}$ ), the pigments were transferred to a small volume of $n$-hexane. The crude extracts were examined spectrophotometrically in a Bausch and Lomb Spectronic 505 recording spectrophotometer. Six types of curves were distinguished (see Fig. I to 6).

For the purposes of diagnosis, the pigments can be separated and provisionally identified by their differential migration rates in I-dimensional chromatograms on (a) alumina paper (Schleicher and Schuell No. 667 or 288), using as solvent a mixture of benzene + ethyl acetate + isopropanol (10+10+I, v/v/v; see Fig. 7) and (b) silica paper (S. and S. No. 287 or 966), using as solvent a mixture of acetone and petrol ether $(9+$ I v/v; see Fig. 8).

5. Penicillin tolerance. Penicillin G (Calbiochem), sterilized by filtration, was incorporated at various concentrations into I \% agar preparations of medium $I$ or 2 in Petri dishes. Two to seven days after inoculation the plates were examined for evidence of growth or inhibition.

6. Lauryl sulphate tolerance. Plates were prepared with medium I or 2 containing I \% agar with or without 0.0 I \% Na lauryl sulphate (Quadling, Cook \& Colwell, 1964), and 2 to 7 days after inoculation were examined for evidence of growth or inhibition.

7. Salinity tolerance. Plates of $\mathrm{I} \%$ agar medium containing $\mathrm{KNO}_{3} 0.5 \mathrm{~g} . / 1 ., \mathrm{Na}$ glycerophosphate $0 \cdot \mathrm{I}$ g./l., tris buffer $\mathrm{I} \cdot 0 \mathrm{~g}$./l., trace-element solution $\mathrm{I} \cdot 0 \mathrm{ml} . / \mathrm{l}$., Tryptone $\mathrm{I} \cdot 0 \mathrm{~g} . / 1$., and yeast extract $\mathrm{I} \cdot 0 \mathrm{~g} . / 1$., were prepared with distilled water, halfstrength sea water, normal sea water, or double-strength sea water, adjusted to $\mathrm{pH} 7 \cdot 2$. Two to seven days after inoculation they were examined for evidence of growth or inhibition.

8. Temperature limits for growth. Replicate plates of a I \% agar medium, I or 2 as appropriate, were inoculated and incubated at room temperature (about $24^{\circ}$ ), at $35^{\circ}$, and at $40^{\circ}$. Growth was recorded after 4 to 7 days.

9. Survival at $+3^{\circ}$. One-week-old cultures of each strain, grown at room temperatures, were kept refrigerated at $+3^{\circ}$, and were tested for viability at intervals of $o, I$, 4 and 7 days by spotting on to medium I or 2, as appropriate. Those strains surviving at $+3^{\circ}$ for I week were recorded as positive.

I0. Survival at $-196^{\circ}$. A I-ml. sample of each strain, grown for 2 weeks in its normal culture medium and adapted in $10 \%$ glycerol for I day, was immersed in liquid nitrogen $\left(-196^{\circ}\right)$ for $2 \mathrm{hr}$. It was then thawed and spotted on to medium $\mathrm{I}$ or 2 , as 
appropriate. Survival was revealed by visible growth appearing within I week (Sanfilippo \& Lewin, I969).

II. Cellulose and carboxymethylcellulose digestion. None of our strains clearly softened or otherwise digested native cellulose in the form of filter paper, powdered cellulose, or cellophan. (Strips of cigarette paper partly submerged in liquid mineral medium ( $\mathrm{I}$ or 2 as appropriate), showed partial or complete disintegration at the level of the meniscus by certain strains (notably $\mathrm{B}-\mathrm{A}$ ) not included in this survey, showing that the paper was potentially digestible.)

Three per cent sodium carboxymethyl cellulose (high-viscosity: General Biochemicals, Chagrin Falls, Ohio), dissolved in medium I or 2, and sterilized by autoclaving, set on cooling to about the firmness of $\mathrm{I} \%$ agar. Separate tubes were inoculated with each strain, incubated at room temperature, and observed for I week. Liquefaction was taken as evidence of cellulase activity.

I 2. Starch hydrolysis. Plates were prepared containing $2 \cdot 0 \mathrm{~g}$. soluble starch/1. and $\mathrm{I} \%$ agar in medium I or 2 , sterilized by autoclaving. One to three days after inoculation, when the colonies showed appreciable growth, they were flooded with Lugol solution (iodine $0.3 \%, \mathrm{KI} 0.7 \%$ ). A pale halo provided evidence for extracellular amylase.

13. Agar liquefaction. One per cent agar 'deeps' of medium I or 2 were inoculated and incubated for 3 days at $30^{\circ}$. Agar liquefaction occurred in some cases; in certain others there was only appreciable softening and/or pitting of the surface.

I4. Alginate liquefaction. Medium I or 2, without agar, supplemented with $3 \%$ potassium alginate (Grade IKR, Kelco, San Diego, California), was dispensed in tubes; after autoclaving it set to a sloppy gel. Individual tubes were inoculated with each strain. Liquefaction, observed after about 7 days, was recorded as evidence for alginase activity.

I 5. Gelatin liquefaction. Medium I or 2, prepared with $10 \%$ Difco gelatin, without agar, set after autoclaving to a gel. Individual tubes were inoculated with each strain. After a growth period of 3 to 5 days, the tubes were refrigerated at $+3^{\circ}$. Failure to solidify indicated proteolytic activity.

I6. Litmus milk media. Media were prepared with a mixture of skimmed milk (final concentration $50 \%$ ) and litmus (final concentration $\mathrm{I} \%$ ), each sterilized separately. To preclude coagulation, the milk was autoclaved at $120^{\circ}$ for only $5 \mathrm{~min}$. For the marine strains, the medium was supplemented with Rila 'sea-salt mixture', final concentration $4 \%$. Before inoculation, the tubes were incubated at $30^{\circ}$ for a week to ensure that they were not contaminated. After inoculation, they were returned to the $30^{\circ}$ incubator and examined at intervals for 2 weeks, observations being made for clotting, subsequent dissolution of the clots, acidification (indicated by the litmus turning pink) and reduction of the litmus (indicated by bleaching below the surface).

17. Catalase production. One-week-old agar slant cultures, on medium I or 2 as appropriate, were flooded with 10\% hydrogen peroxide. Copious evolution of bubbles was evidence for catalase activity.

I8. Hydrogen sulphide production. Tubes containing $0 \cdot \mathrm{I}$ g. L-cysteine hydrochloride/1. (sterilized by filtration) in medium $\mathrm{I}$ or 2 were inoculated with the various strains. Strips of filter paper impregnated with lead acetate were folded over the lip of the tube, which was covered as usual with a glass 'Cencap' (Central Scientific Co.). Blackening of the paper strip, usually in less than a week, indicated $\mathrm{H}_{2} \mathrm{~S}$ production. 
19. Tyrosine degradation. Plates were prepared containing a I \% agar medium, I or 2 , to which had been added $5.0 \mathrm{~g}$. powdered L-tyrosine/l. (The medium was cloudy white due to undissolved tyrosine.) Three to seven days after inoculation the plates were examined for growth, for production of a coloured halo, varying from pink through red to black (evidence for a tyrosine oxidase), and for clearing of the opalescence.

20. DOPA oxidase. DL-3,4-dihydroxyphenylalanine (Calbiochem) (0.1 g./1.) was added to I \% agar medium I or 2; after being autoclaved, the medium became grey. Poured Petri dishes were inoculated, incubated and examined after 4 to 7 days for growth and for the appearance of a darker halo and/or clearing around each colony site.

2I. Nitrate reduction. The test was a modification of that described in the Difco Manual (1965), media being based on formula I or 2 as appropriate. To a week-old slant culture a few drops each of sulphanilic acid and $\alpha$-naphthylamine reagent were added. A distinct pink or red colour, appearing within a few minutes, indicated the presence of nitrite, presumably formed by the reduction of nitrate.

22. Carbon sources for growth. The experimental procedures for flexibacteria are somewhat more complicated than they are for less fastidious bacterial genera such as Pseudomonas. The interpretation of many of the data on the utilization of carbon sources is open to question, since the majority of the organisms in the present investigation require other organic factors for growth, and for a number of strains these factors, present in Tryptone or yeast extract, have not yet been defined. It was, therefore, necessary to add low concentrations of complex organic growth supplements to the basal media ( $0.2 \mathrm{~g}$. Casamino acids/l. for freshwater strains; $0.2 \mathrm{~g}$./1. each of Tryptone and yeast extract for marine strains), and to seek evidence for stimulation of growth, beyond that shown in the controls, when various non-nitrogenous carbon compounds were added. The tests were made on agar medium in Petri plates. Sugars were autoclaved separately. We used at each substrate tested I.0 g./l. and $5.0 \mathrm{~g} . / 1$., and assessed growth stimulation subjectively 4 to 7 days after inoculation. In some cases, the higher concentration proved inhibitory to growth.

23. Nitrogen sources. The freshwater strains were tested in separate tubes, each containing $5 \mathrm{ml}$. of liquid medium of the composition given for medium I (except for the $\mathrm{KNO}_{3}$ and Casamino acids), to which one of the following was added ( $\mathrm{g}$./l.): Tryptone, Casamino acids, sodium glutamate, potassium nitrate. Control tubes did not contain an added source of nitrogen. After inoculation, the cultures were constantly shaken at $30^{\circ}$. The marine strains were similarly studied in a synthetic-sea water medium $\left(\mathrm{NaCl} 25^{\circ} \circ \mathrm{g}\right.$./1., $\mathrm{MgSO}_{4} \cdot 7 \mathrm{H}_{2} \mathrm{O} 5^{\circ} 0 \mathrm{~g}$./l., $\mathrm{CaCl}_{2} \cdot 2 \mathrm{H}_{2} \mathrm{O}$ I.0 g./l., and $\mathrm{KCl} \mathrm{I} \cdot 0 \mathrm{~g} . / 1$.) supplemented with tris buffer $\left(\mathrm{pH}_{7} \cdot 2\right) \mathrm{I} \cdot 0 \mathrm{~g} . / 1 .$, trace-element solution $\mathrm{I} \cdot 0 \mathrm{ml}$./1., thiamine $\mathrm{I} \cdot 0 \mathrm{mg}$./1., cobalamin $\mathrm{I} \cdot 0 \mu \mathrm{g}$./l., and glucose (autoclaved separately) I $0 \mathrm{~g}$. $/ \mathrm{l}$. Growth after 2 to 5 days was compared with that in the appropriate control tube, from which a fresh inoculation was made into a similar set of media. These were grown and evaluated as before, the object of this second subculture being to minimize the effects of carry-over of nitrogenous substances with the original inoculum.

24. Amino acid requirements. The specific amino acid requirements of certain selected strains were investigated as described for Saprospira thermalis (Lewin, $1965 b$ ).

25. Vitamin requirements. The specific vitamin requirements of certain selected strains were studied as previously described (Lewin, $1965 b$ ).

26. Nucleic acid factor(s). Most species of Saprospira grandis, when grown in other- 
wise defined nutrient media without Tryptone or yeast extract, required the addition of a small quantity (c. Io to $30 \mathrm{mg}$./ $/$.) of a nucleic-acid hydrolysate, containing growth factor(s) not yet identified. More detailed studies of the nutrition of $S$. grandis will be described elsewhere.

27. Anaerobic growth. Stabs of each strain were made in semi-solid (0.25\% agar) medium, I or 2 as appropriate, and incubated at $30^{\circ}$. Observations were made at intervals for about 2 weeks, to determine at where, at or below the surface, growth was best.

28. Chitin. A $2 \%$ suspension of chitin (Eastman P 2064) in molten I \% agar medium I or 2 as appropriate was poured into plates and cooled. Cultures were spotted on the surface and incubated at room temperatures for I to 2 weeks. Clearing of the turbidity indicated digestion of the chitin.

29. Indole. Kovacs reagent, $0.2 \mathrm{ml}$. (Difco Manual, 1965), was added to $4 \mathrm{ml}$. of a $24 \mathrm{hr}$ culture growing in medium $\mathrm{I}$ or 2 , as appropriate, containing Tryptone $(10.0 \mathrm{~g} . / 1$.$) . A red colour at the interface indicated the formation of indole.$

30. 'Vibriostat'. A $0.9 \%$ aqueous solution of 'Vibriostat' (pteridine compound o/I29, kindly supplied by Dr G. L. Bullock, U.S. Fish and Wildlife Service, Kearnysville, W. Va., U.S.A.; see Shewan, Hodgkiss \& Liston, 1954) was sterilized by filtration and added to sterile I \% agar preparations of medium I or 2, as appropriate, to give the following final concentrations (mg./ml.): 0.9, 0.09, 0.009, 0. After each strain was spotted on the agar, the plates were incubated at $30^{\circ}$ and examined at intervals for about a week for signs of growth.

3I. Ammonia production. On a white tile one drop of a 48 -hr culture was mixed with one drop of Nessler solution. A deep yellow colour would have indicated ammonia production by the organisms. (See Peltier, Georgi \& Lindgren, I959.)

\section{Light microscope observations}

As prime and sole requirements for consideration in this survey, all of the strains were capable of some degree of motility by gliding but were devoid of flagella ( $c f$. Lautrop, I965-67). In other words, they were motile, though they did not swim: they may be described as repent but not natant. The more elongate forms were also capable of active bending. The filaments of all strains are about 0.5 to I $\mu \mathrm{m}$. in width, and ranged from five to many hundreds of $\mu \mathrm{m}$. in length. (Tabulated lengths are only approximate, because of the considerable range of filament lengths encountered even within a single culture.) In some strains the longer filaments consisted of many cellular units, delimited by cross walls, but unmarked by constrictions like those in certain colourless types such as Vitreoscilla spp. No extended tapering, no attachment holdfast, and no other cellular differentiation was observed in these strains, which thus differed from Leucothrix and Thiothrix. (In some strains the cells were seen to taper somewhat at the ends; this was evident even in living mounts examined by phase-contrast microscopy. However, since it is difficult to distinguish the strains as 'tapered' or 'not tapered', and since this feature seemed to vary even within a single culture as it aged, tapering at the ends of the cells has not been counted among the distinctive features of taxonomic value.) They were generally less refractile than most eubacteria ( $c f$. Stanier I947). Under some circumstances most strains tended to produce lateral inflations or spherical bodies, probably akin to sphaeroplasts; these were especially common in old cultures, and probably resulted from unfavourable or deteriorating cultural conditions. 
None of the strains forms true endospores. (One of the isolates (B-A) formed abundant refractile microcysts in every colony examined, though without any apparent differentiation of a fruiting structure; it was capable of digesting cellulose paper; and it was the only one of the strains in this survey which apparently lacked a carotenoid pigment. The GC value, 56.5\% (Mandel \& Lewin, 1969) was much larger than that of any of the other strains examined here. For these reasons we did not consider it further in this survey.)

\section{RESULTS}

All of the flexibacteria studied here appear to be obligately aerobic, growth in stab cultures being restricted to the uppermost I to $3 \mathrm{~mm}$. All strains are Gram-negative. All are some shade of yellow, orange, pink or red, and all contain one or more carotenoid pigments. Four major pigment groups have been distinguished on the basis of their absorption spectra and their behaviour on Celite diatomite columns. All but three of our strains can be allocated to one or another of these groups. They have been characterized by Fox \& Lewin (1963) and by Aasen \& Jensen (I966 a, b,c). Two strains (assignable to one species) produce pigment of a fifth type, and one strain a sixth type. Absorption curves of the crude total lipid extracts in $n$-hexane, containing the carotenoid pigments, are given for representatives of each of these six pigment types (Fig. I-6). Their absorption maxima in $n$-hexane are shown with other data in Table 7 , on p. 170 .

The results of the specific discriminatory tests are summarized in Tables 2 to 6. For convenience, the organisms have been subdivided in separate tables according to the genera in which we ultimately placed them: Cytophaga, Flexibacter, Microscilla, Flexithrix, Saprospira and Herpetosiphon (Lewin, 1969b). The tables summarize various physical and physiological features, enzymic activities, and nutritional characteristics, in that order. In each table, the columns are numbered to correspond with the tests described in the Methods section. Explanatory notes for each column of the tables precede the tables.

Other tests, briefly described in the Methods section, revealed no significant differences among the strains or were equivocal for experimental reasons. They included tests 27 (anaerobiosis), 28 (chitin digestion) and 29 (indole formation), which were all negative, and 30 , in which growth of all strains was inhibited by Vibriostat at a concentration of $0.9 \mathrm{mg}$./1. The results of test 3I (ammonia production) were variable and not reproducible in the various nutrient media used. Dr P. Grilione (personal communication) tested several of our strains for precipitation in the presence of rabbit antisera prepared against Myxococcus fulvus, $M$. virescens, M. xanthus, Archangium sp. and Polyangium sp. No positive reactions were detected under conditions in which homologous antigens were precipitated (Grilione, 1968). Flexibacteria tested included: Flexibacter aurantiacus (CR-I34, DWO); F. roseolus (CR-I4I, CR-I 55); F. elegans (NZ-I); F. flexilis (BA-24, CR-63, CR-81, FLE); F. giganteus (CR-I03, CR-I04); F. ruber (GEY); F. sancti (BA-3, BA-23, MIC); Herpetosiphon geysericolus (GC-42); Saprospira thermalis (BEG).

\section{DISCUSSION}

There was a close correlation between the salinity of the original habitats and the salt tolerance of the strains in culture: few marine species tolerated transfer to fresh- 


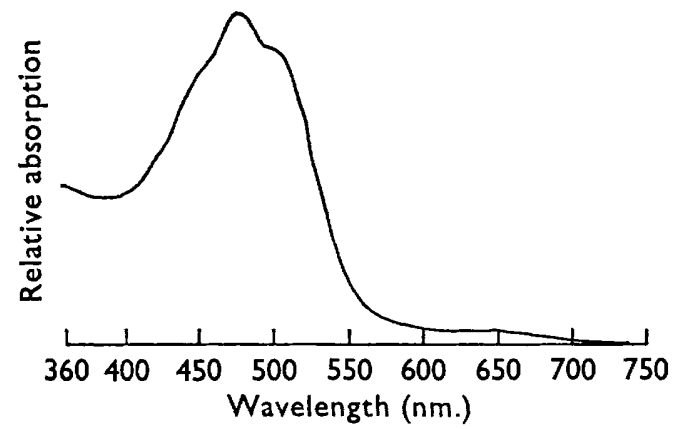

Fig. I

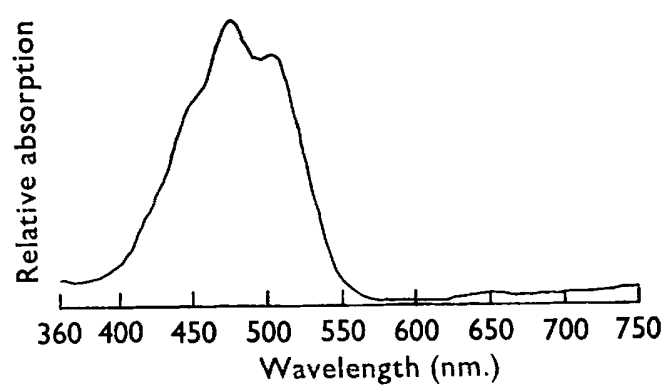

Fig. 2

Fig. I. Absorption curve of pigment extract, type I, from Flexibacter ruber (strain GEY), in $n$-hexane.

Fig. 2. Absorption curve of pigment extract, type II, from Saprospira thermalis (strain BEG), in $n$-hexane.

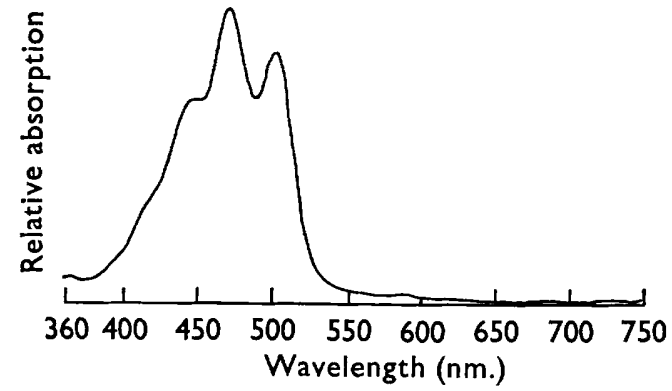

Fig. 3

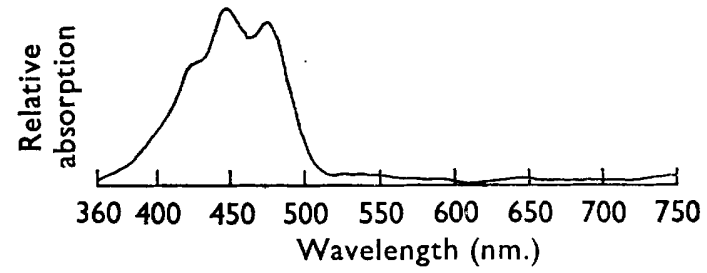

Fig. 4

Fig. 3. Absorption curve of pigment extract, type III, from Flexibacter elegans (strain NZ-I), in $n$-hexane.

Fig. 4. Absorption curve of pigment extract, type IV, from Cytophaga lytica (strain B-9), in $n$-hexane.

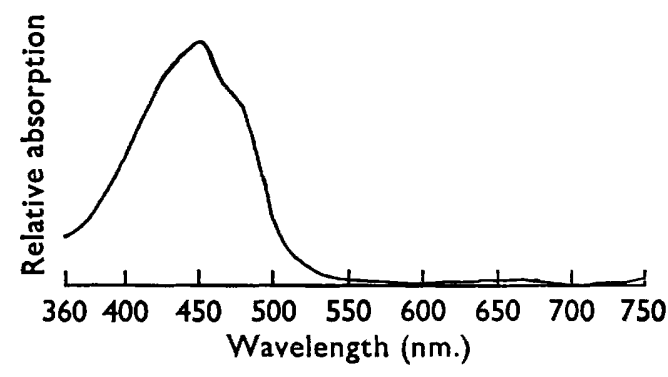

Fig. 5

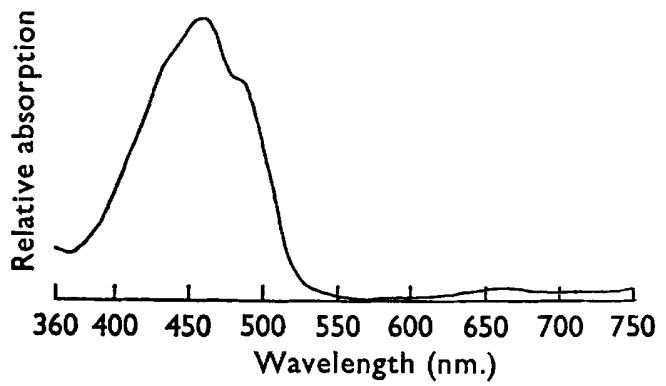

Fig. 6

Fig. 5. Absorption curve of pigment extract, type V, from Flexibacter aurantiacus (strain DWo), in $n$-hexane.

Fig. 6. Absorption curve of pigment extract, type VI, from Cytophaga latercula (strain sio- 1 ), in $n$-hexane. 
water media, and few freshwater species grew in media prepared with sea water, though there were some exceptions in each direction. The strains isolated from hot springs were not markedly thermophilic, probably because we had made no attempt to isolate them at elevated temperatures. It is doubtful whether other valid correlations can be made between the locality of origin and the nature of the strains isolated, in view of the vicissitudes of the journeys between the points of collection and isolation. Those isolated from the vicinities of the Scripps Institution of Oceanography, California, and the Department of Microbiology at San José, Costa Rica probably include certain less robust forms which might not have survived several days in the postal systems across the world; but we have no experimental information beyond that presented here in the tabulation of physiological data.

It is of interest that a number of the strains examined in this survey proved to require certain amino acids in the nutrient medium. The presence of such compounds in natural waters has been reported by various investigators, but in concentrations considerably lower than those we used. Thus Briggs (I962) reported total free amino acids in lake waters to be in the region of a few micrograms per litre; Degens, Reuter \& Shaw (1964) found as much as $3 \mathrm{mg}$./g. (dry weight) in marine sedimentary mud. It would be interesting to have determinations for hot-spring waters, but no reference was found to such data. (Sarbutt, 1964, recorded only inorganic solutes.) In media containing a limiting amino acid at concentrations less than 5 to Io mg./1., growth of most auxotrophic strains was not appreciably better than in the controls without the essential factor. We may conclude that the concentrations of free amino acids found in natural waters would not suffice for appreciable growth of such fastidious flexibacteria unless the organisms are able to accumulate them effectively. One is, therefore, led to conclude that the majority of the strains requiring specific amino acids for growth obtain these compounds by the action of extracellular enzymes on proteins in their environment. Their proteolytic activities have been demonstrated in the present study (see Tables 3 to 6 , in which are summarized data on gelatin digestion, milk clotting and clot lysis, etc.). Correlated with this must be the ecological roles of such strains. Thus Chondrococcus columnaris, a myxobacterial pathogen of fish (Anacker \& Ordal, 1959) is presumably able to break down tissues in sites of infection. Certain myxobacteria have also been recorded as capable of digesting algae (Geitler, 1924) or other bacteria (Kononenko, 1937; Snieszko, McAllister \& Hitchner, I942; Singh, 1947).

Dworkin (1966) suggested the interesting possibility that gliding motility might be of selective advantage to organisms dependent on the location and digestion of insoluble substrates for their nutrition.

The colour of the organisms seen in masses seems to be a relatively constant character. In the course of laboratory subculturing for several years, we have not observed any case of a major change in the general colour of any strain, though the intensity of pigmentation is in many strains under the influence of light (see Lewin, 1965b, 1969a; cf. Myxococcus xanthus, Burchard \& Dworkin, 1966) or nutritional factors (Lewin, $1965 b$ ).

It is worth emphasizing that none of our strains was tinged with green, although greenish myxobacterium-like organisms have been reported by Winogradsky (e.g. Cytophaga tenuissima, Winogradsky, 1929) and by Imshenetsky \& Solntseva (1936). It seems to us likely that the reported greenish colour was in some cases produced by 
a combination of yellow carotenoid pigments with greyish extracellular melanins, and, in others a consequence of refraction by patches of aligned cells. If, in fact, real green pigmentation occurs among these gliding forms, we should envisage the possibility that it may be attributable to chlorophylls, or even to mixtures of carotenoids with biliproteins. Photosynthetic bacteria, which contain bacteriochlorophylls and do not evolve oxygen during photosynthesis, are normally flagellate and presumably eubacterial. Blue-green algae, which typically contain chlorophyll and a red or blue bilin pigment, evolve oxygen in photosynthesis. Intermediates are unknown; but they might be worth looking for among the green gliding myxobacteria, if such exist.

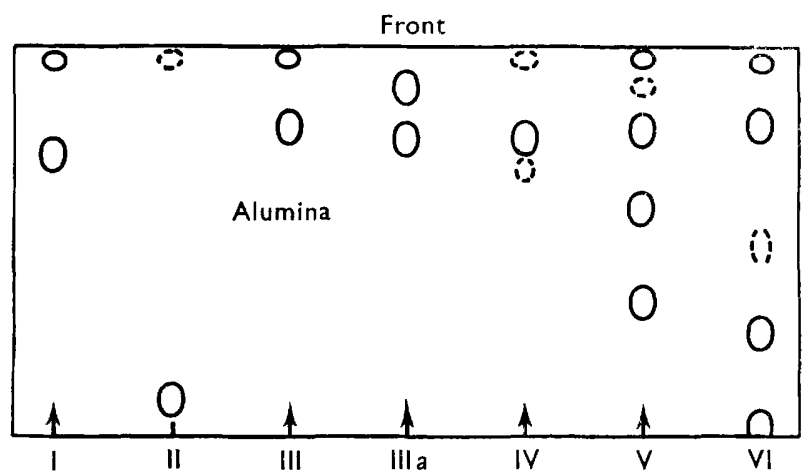

Fig. 7. I-dimensional chromatograms of crude carotenoid extracts on alumina paper (Schleicher and Schuell no. 288), using as solvent a mixture of benzene + ethyl actate + isopropanol $(\mathrm{IO}+10+\mathrm{I} \mathrm{v} / \mathrm{v})$. The following representative types were selected:

$\begin{array}{lll}\text { Pigment type } & \text { Species (see Lewin, } 1969 b \text { ) } & \text { Strain } \\ \text { I } & \text { Flexibacter roseolus } & \text { CR-14I } \\ \text { II } & \text { Saprospira thermalis } & \text { BEG } \\ \text { III } & \text { S. grandis } & \text { WH } \\ \text { III } & \text { S. toviformis } & \text { A-I } \\ \text { IV } & \text { Flexithrix dorotheae } & \text { QQ-3 } \\ \text { V } & \text { F. aurantiacus } & \text { DWO } \\ \text { VI } & \text { Cytophaga latercula } & \text { SIO-I }\end{array}$

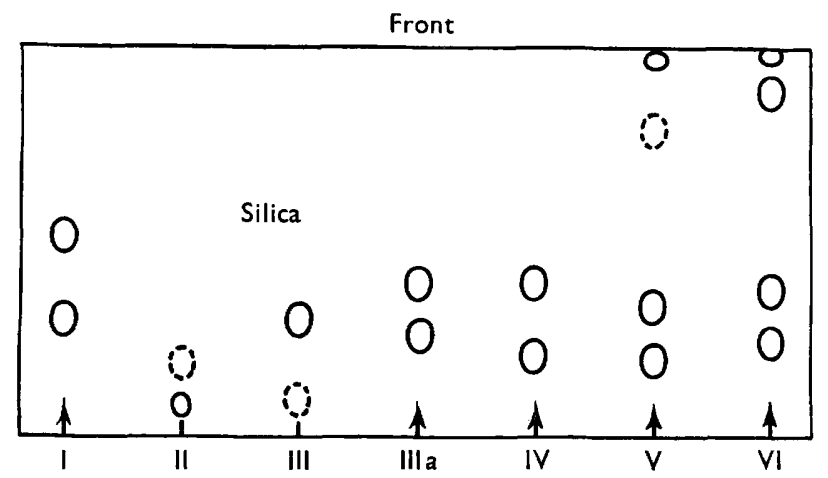

Fig. 8. I-dimensional chromatograms of crude carotenoid extracts on silica paper (Schleicher and Schuell no. 966), using as solvent a mixture of acetone and petrol ether (30-60 b.p.) $(9+\mathrm{I} v / \mathrm{v})$. For key to pigment types, etc., see legend to Fig. 7. 
We acknowledge with thanks the kindness of the many persons who supplied cultures or mud samples, from a large proportion of which we were able to isolate fresh strains for this study (see Table I). Dr Santos Soriano, of the University of Buenos Aires, offered valuable suggestions on the initial choice and design of the discriminatory tests. Mrs A. Sanfilippo helped with routine maintenance of the stock cultures and with many of the nutritional experiments throughout these studies. Dr R. E. Reichle examined the lysates for the presence of rhapidosomes.

Most of the preliminary studies on the carotenoid pigments were undertaken by Mrs Dorothy White, whose untimely death was a sad loss. Dr D. L. Fox and Mr G. Crozier provided expert guidance and assistance with the extraction and spectrophotometric analyses of these pigments, and Dr F. T. Haxo permitted us to use the Carey spectrophotometer in his laboratory. Dr S. L. Jensen and Mr A. J. Aasen, of the Tekniske Høgskole, Trondheim, isolated and chemically characterized certain carotenoids from mass cultures grown at the Karolinska Institute, Stockholm, by Miss Margareta Fall under the direction of Dr C.-G. Hedén. Dr Jensen also suggested the two paper-chromatographic systems used for preliminary determinations of carotenoids.

This work was supported largely by grants G-I6339, from the National Science Foundation, and GM-60I03, from the National Institutes of Health. One of us, R.A.L., was a Research Participant in the Tropical Biology Programme at San José, Costa Rica, in the summer of 1963 , supported by grant GE-4507 from the National Science Foundation and using facilities kindly placed at his disposal by Dr Bernal Fernandez.

This paper is a Contribution from the Scripps Institution of Oceanography.

\section{REFERENCES}

Aasen, A. J. \& Jensen, S. L. (I966a). The carotenoids of flexibacteria. II. A new xanthophyll from Saprospira grandis. Acta chem. scand. 20, $8 \mathrm{II}$.

AASEN, A. J. \& JENSEN, S. L. ( $1966 b$ ). Carotenoids of flexibacteria: the structures of saproxanthin, flexixanthin and deoxy-flexixanthin. Tidsskr. Kjemi Bergv. Metall. 26, 125.

AASEn, A. J. \& JeNSEN, S. L. (1966c). Carotenoids of flexibacteria. IV. The carotenoids of two further pigment prototypes. Acta chem. scand. 20, 2322.

ANACKer, R. L. \& ORDAL, E. J. (1959). Studies on the myxobacterium Chondrococcus columnaris. J. Bact. 78, 25.

BrIGGS, M. H. (1962). The presence of free sugars, peptides and amino acids in filtered lake waters. Life Sciences 8, 377.

BURCHARD, R. P. \& Dworkin, M. (I966). Light-induced lysis and carotenogenesis in Myxococcus xanthus. J. Bact. 9I, 535.

CARPson, R. V. \& PACHA, R. E. (1968). Procedure for the isolation and enumeration of myxobacteria from aquatic habitats. Appl. Microbiol. r6, 795.

Colwell, R. R. (1969). Numerical taxonomy of flexibacteria. J. gen. Microbiol. 58, 207.

Degens, E. T., Reuter, J. H. \& Shaw, K. N. F. (1964). Biochemical compounds in offshore California sediments and sea waters. Geochim. cosmochim. Acta $\mathbf{2 8 ,} 45$.

Difco Manual (1965). 9th ed. Detroit, Michigan: Difco Laboratories, Inc.

Dworkin, M. (1966). Biology of the Myxobacteria. Ann. Rev. Microbiol. 20, 75.

FAGER, E. W. (1969). Recurrent group analysis in the classification of flexibacteria. J. gen. Microbiol. 58,179 .

Fox, D. L. \& Lewin, R. A. (1963). A preliminary study of the carotenoids of some flexibacteria. Can. J. Microbiol. $9,753$.

GeITLER, L. (1924). Ueber Polyangium parasiticum $\mathrm{n}$. sp., eine submerse, parasitische Myxobacteriacea. Arch. Protistenk. 5o, 67. 
Grilione, P. (1968). Serological reactions of some higher Myxobacteria. J. Bact. 95, 1202.

IMSHENETSKY, A. \& SolNTSEVA, L. (1936). On aerobic cellulose-decomposing bacteria. Publ. Acad. Sci. U.S.S.R. Mat.-Nat. Sci. 6, III5.

KoNONENKo, E. V. (1937). Lysis of the causative agent of cotton wilt, Verticillium dahliae, provoked by some myxobacteria. Mikrobiologiya 6, 7 I 6.

Lautrop, H. (1965-67). Gliding motility in bacteria as a taxonomic criterion. Publ. Fac. Sci. Univ. J. E. Purkyne: Brno 35, 322.

LewIN, R. A. (1963). Rod-shaped particles in Saprospira. Nature, Lond. 198, 103.

LEwIN, R. A. (1965a). Freshwater species of Saprospira. Can. J. Microbiol. II, I35.

LEwIN, R. A. $(1965 b)$. Isolation and some physiological features of Saprospira thermalis. Can. J. Microbiol. II, 77.

LewIN, R. A. (1969a). Flexithrix dorotheae gen. et sp. n. (Flexibacterales): and suggestions for reclassifying sheathed bacteria. Can. J. Microbiol. (in the press).

LewIN, R. A. (1969b). A classification of flexibacteria. J. gen. Microbiol. 58, 189.

MANDEl, M. \& Lewin, R. A. (I969). Deoxyribonucleic acid base composition of flexibacteria. J. gen. Microbiol. 58, $17 \mathrm{I}$.

MAYER, D. (1967). Ernährungsphysiologische Untersuchungen an Archangium violaceum. Arch. Mikrobiol. 58, 186.

Peltier, G., Georgi, C. \& Lindgren, L. (1959). Laboratory Manual for General Bacteriology. New York: John Wiley and Sons.

Quadling, C., Cook, F. D. \& Colwell, R. R. (1964). Taxonomy of newly isolated Cytophaga strains. Bact. Proc. p. 28.

Reichle, R. E. \& Lewin, R. A. (I968). Purification and structure of rhapidosomes. Can. J. Microbiol. I4, 2 II.

Sanfilippo, A. \& Lewin, R. A. (1969). Preservation of viable flexibacteria at low temperature. Can. $J$. Microbiol. (in the press).

SarbutT, J. V. (I964). A chemical survey of the hot spring and drillhole waters of. Taupo borough. N.Z. Jl Sci. 7, $49 \mathrm{I}$.

Shewan, J. M., Hodgkiss, W. \& Liston, J. (1954). A method for the rapid differentiation of certain non-pathogenic, asporogenous bacilli. Nature, Lond. 173, 208.

SINGH, B. N. (1947). Myxobacteria in soil and composts; their distribution, number and lytic action on bacteria. J. gen. Microbiol. x, I.

SNieszko, S. F., MCAllister, J. \& HitchNeR, E. R. (1942). On the biology of certain myxobacteria. Q. Bull. Polish Inst. Arts Sci. America $\mathbf{1}, 65 \mathrm{I}$.

Soriano, E. \& Lewin, R. A. (1965). Gliding microbes: some taxonomic reconsiderations. Antonie van Leeuwenhoek 3I, 66.

STANIER, R. Y. (1947). Studies on nonfruiting myxobacteria. I. Cytophaga johnsonae, n. sp., a chitindecomposing myxobacterium. J. Bact. 53. 297.

WinOGRADSKY, S. (I929). Études sur la microbiologie du sol. Sur la dégradation de la cellulose dans le sol. Annls Inst. Pasteur, Paris 43, 549.

Zehnder, A. \& Hughes, E. O. (1958). The anti-algal activity of actidione. Can. J. Microbiol. 4, 399. 
Table I. Code designations, names as proposed in another paper of this series (Lewin, 1969b), and sources of strains of flexibacteria studied

The genera are alphabetically arranged. Within each genus the species are ordered as in the conspectus presented elsewhere (Lewin, $1969 b$; Table $\mathrm{I}$ ).

\section{Notes to Table I}

${ }^{1}$ Deposited as ATCC I 5854, NCMB 292.

2 Supplied as 'Cytophaga aurantiaca'.

${ }^{3}$ Supplied as 'Cytophaga psychrophila'.

* Supplied as 'Flexoscilla Strain 8Q'.

' Supplied as 'Microscilla sp'.

${ }^{6}$ All strains of Cytophaga spp., Microscilla spp., Flexibacter aurantiacus var. copepodarum, Flexithrix dorotheae, Herpetosiphon cohaerens, $H$. persicus, $H$. nigricans, Saprospira grandis and $S$. toviformis were isolated from marine shores.

${ }_{7}$ All pure cultures were isolated by R. A. L. except for those indicated by a superscript as follows:

${ }^{8}$ Isolated by R. A. MacLeod.

${ }^{9}$ Isolated by W. F. Blankley.

${ }^{10}$ Isolated by A. Sanfilippo.

11 Isolated by M. Dworkin.

12 Isolated by J. G. Holt.

${ }^{13}$ Isolated by S. Soriano.

${ }^{14}$ Isolated by A. Cataldi.

* Strain designated as type or neotype.

\begin{tabular}{|c|c|c|c|c|}
\hline Strain & \multicolumn{3}{|l|}{ Cytophaga } & Collected by ${ }^{7}$ \\
\hline SIO-I & ${ }^{*}$ C. latercula & La Jolla, Calif. & $\begin{array}{l}\text { Sea-water aquarium } \\
\text { outflow }\end{array}$ & R. A. Lewin \\
\hline B-9 $9^{1}$ & C. lytica & B.C., Canada & Sea water & R. A. MacLeod ${ }^{8}$ \\
\hline WFB-2 I & C. lytica & La Jolla, Calif. & $\begin{array}{l}\text { Sea-water aquarium } \\
\text { outflow }\end{array}$ & W. F. Blankley ${ }^{9}$ \\
\hline BON & C. lytica & La Jolla, Calif. & $\begin{array}{l}\text { Sea-water aquarium } \\
\text { outflow }\end{array}$ & D. D. Bonnett \\
\hline ENS & C. lytica & Ensenada, B.C., Mexico & Silt & R. A. Lewin \\
\hline LIM-2I & ${ }^{*}$ C. lytica & Limón, Costa Rica & Mud & R. A. Lewin \\
\hline DD-I & C. diffluens (?) & Bermuda & White sand & J. Beers \\
\hline DUB-4 & C. $d$. var. aprica & Dubrovnik, Yugoslavia & Mud & R. A. Lewin ${ }^{\text {I0 }}$ \\
\hline ST-I & C. $d$. var. aprica & Bimini, B.W.I. & $\begin{array}{l}\text { Sand under I metre } \\
\text { depth }\end{array}$ & E. Koschen \\
\hline $\mathrm{JL}-4$ & ${ }^{*} C . d$. var. aprica & Kailua, Hawaii & Rocky sand & R. W. Grigg \\
\hline Q-I & ${ }^{*} C . d$. var. carnea & Split, Yugoslavia & $\begin{array}{l}\text { Coarse, grey-brown } \\
\text { sand }\end{array}$ & $\begin{array}{l}\text { Director, Oceanogr. } \\
\text { Institute }\end{array}$ \\
\hline Y-I & C. diffluens & Zanaiban, Nigeria & Grey, silty sand & $\begin{array}{l}\text { Director, } \\
\text { E.A.F.R.O. }\end{array}$ \\
\hline GOL-I 2 & C. diffluens & Golfito, Costa Rica & Mud & R. A. Lewin \\
\hline$N-3$ & C. diffluens & Nosy Bé, Madagascar & Sand & M. Angot, R. Planke \\
\hline NN-3 & C. diffluens & $\begin{array}{l}\text { Canoe Beach, Tema, } \\
\text { Ghana }\end{array}$ & $\begin{array}{l}\text { Coarse, greenish-brown } \\
\text { sand }\end{array}$ & E. Kwei, J. Teya \\
\hline B-I & ${ }^{*}$ C. diffluens & Bombay, India & $\begin{array}{l}\text { Black sandy mud, } \\
\text { lower littoral }\end{array}$ & Y. Freitas \\
\hline LIM-I & C. diffluens & Limón, Costa Rica & Mud & R. A. Lewin \\
\hline $0-2$ & C. diffluens & $\begin{array}{l}\text { Kaneohe Bay, Oahu, } \\
\text { Hawaii }\end{array}$ & $\begin{array}{l}\text { Fine sand, upper } \\
\text { littoral }\end{array}$ & R. Hiatt \\
\hline \multicolumn{5}{|c|}{ Flexibacter } \\
\hline SIO-4 & ${ }^{*} F$. litoralis & La Jolla, Calif. & $\begin{array}{l}\text { Sea-water aquarium } \\
\text { outflow }\end{array}$ & R. A. Lewin \\
\hline $\mathrm{DWO}^{2}$ & ${ }^{*} F$. aurantiacus & Minneapolis, Minn. & Garden soil & M. Dworkin ${ }^{11}$ \\
\hline $\begin{array}{l}\text { PSY } \\
\text { COP }\end{array}$ & $\begin{array}{l}\text { F. aurantlacus } \\
\text { *F.a. var. }\end{array}$ & La Jolla, Calif. & Offshore copepod & $\begin{array}{l}\text { E. Ordal } \\
\text { B. T. Lang }\end{array}$ \\
\hline & ru & & & \\
\hline
\end{tabular}


Table I (cont.)

\begin{tabular}{|c|c|c|c|c|}
\hline Strain & Name & Location & Habitat $^{6}$ & Collected by ${ }^{7}$ \\
\hline CR-103 & F. giganteus & San José, Costa Rica & Scum on rivulet & R. A. Lewin \\
\hline CR-104 & ${ }^{*} F$. giganteus & San José, Costa Rica & Scum on rivulet & R. A. Lewin \\
\hline CR-I 24 & F. giganteus & San José, Costa Rica & Rivulet, university & R. A. Lewin \\
\hline CR-134 & $\begin{array}{l}{ }^{*} \text { F. a. var. } \\
\quad \text { excathedrus }\end{array}$ & Cartago, Costa Rica & Pool in cathedral & R. A. Lewin \\
\hline CR-I4I & $F$. roseolus & $\begin{array}{l}\text { Agua Caliente, Costa } \\
\text { Rica }\end{array}$ & Hot spring & R. A. Lewin \\
\hline CR-1 55 & ${ }^{*} F$. roseolus & $\begin{array}{l}\text { Agua Caliente, Costa } \\
\text { Rica }\end{array}$ & Hot spring & R. A. Lewin \\
\hline GEY & ${ }^{*} F$. ruber & Geysir, Iceland & Hot spring & R. A. Lewin \\
\hline $\mathrm{FLE}^{4}$ & $\begin{array}{l}\text { *F. flexilis var. } \\
\text { pelliculosus }\end{array}$ & Birch Lake, Minn. & Lakeshore & E. E. Jeffers ${ }^{12}$ \\
\hline CR-63 & ${ }^{*} F$. flexilis & San José, Costa Rica & Lily pond, university & R. A. Lewin \\
\hline CR-8I & F. flexilis & San José, Costa Rica & Rivulet, university & R. A. Lewin \\
\hline A-52 & F. Alexilis & Buenos Aires, Arg. & - & A. Cataldi ${ }^{13}$ \\
\hline WAR- 5 & F. flexilis & $\begin{array}{l}\text { Warner Hot Springs, } \\
\text { Calif. }\end{array}$ & Hot spring & S. Soriano ${ }^{13}$ \\
\hline BA-24 & $\begin{array}{l}* F . f . \text { var. } \\
\text { iolanthae }\end{array}$ & Buenos Aires, Arg. & - & A. Cataldi ${ }^{14}$ \\
\hline $\mathrm{BA}-3$ & ${ }^{*} F$. sancti & Buenos Aires, Arg. & - & A. Cataldi ${ }^{14}$ \\
\hline BA-23 & F. sancti & Buenos Aires, Arg. & - & A. Cataldi ${ }^{14}$ \\
\hline $\mathrm{MIC}^{5}$ & $F$. sancti & Ames, lowa & Soil in feed lot & J. G. Holt ${ }^{12}$ \\
\hline$N Z-I$ & ${ }^{*} F$. elegans & Rotorua, N.Z. & Hot spring & G. R. Fish \\
\hline QQ-3 & $\begin{array}{l}\text { Flexithrix } \\
{ }^{*} \text { F. dorotheae } \\
\text { Herpetosiphon }\end{array}$ & Ernakulum, India & Brown silt & K. N. Sankolli \\
\hline $\mathrm{II}-2$ & ${ }^{*} H$. cohaerens & Biarritz, France & Mid-littoral & $\begin{array}{l}\text { Director, Sta. Biol. } \\
\text { Mar. }\end{array}$ \\
\hline $\mathrm{T}-3$ & ${ }^{*} H$. persicus & $\begin{array}{l}\text { Muigh Inis, Carna Co., } \\
\text { Galway, Ireland }\end{array}$ & Brown mud & $\begin{array}{l}\text { C. O'hEocha, M. de } \\
\text { Valera }\end{array}$ \\
\hline ss-2 & $\begin{array}{l}{ }^{*} H . \text { nigricans } \\
\quad \text { Microscilla }\end{array}$ & Lagos, Nigeria & Brown sand & E. O. Bayagbona \\
\hline $\mathrm{HJ}-\mathrm{I}$ & ${ }^{*} M$. arenaria & $\begin{array}{l}\text { Norse Beach, Puerto } \\
\text { Peñasco, Son., Mexico }\end{array}$ & Brown sand & R. W. Hoshaw \\
\hline $\mathrm{HI}-3$ & $\begin{array}{l}{ }^{*} M . \text { aggregans } \\
\quad \text { var. catalatica }\end{array}$ & Auke Bay, Alaska & $\begin{array}{l}\text { Under frozen sand, } \\
\text { upper littoral }\end{array}$ & J. Quast, R. Haight \\
\hline$Q-3$ & M. aggregans & Split, Yugoslavia & Fine, light-brown sand & $\begin{array}{l}\text { Director, Oceanogr. } \\
\text { Institute }\end{array}$ \\
\hline QQ-I & M. aggregans & Ernakulum, India & Brown sand & K. N. Sankolli \\
\hline QQ-II & M. aggregans & Ernakulum, India & Brown sand & K. N. Sankolli \\
\hline JL-I 3 & M. aggregans & Kailua, Hawaii & $\begin{array}{l}\text { Coarse white sand, } \\
\text { upper littoral }\end{array}$ & R. W. Grigg \\
\hline $\mathrm{NN}-\mathrm{I} 3$ & ${ }^{*} M$. aggregans & $\begin{array}{l}\text { Canoe Beach, Tema, } \\
\text { Ghana }\end{array}$ & Green-brown sand & E. Kwei, J. Teya \\
\hline EE-13 & M. tractuosa & Heligoland, Germany & Red-brown mud & $\begin{array}{l}\text { W. Gunkel, } \\
\text { H. Trekel }\end{array}$ \\
\hline EG-I3 & M. tractuosa & $\begin{array}{l}\text { Normandy, Orne } \\
\text { Estuary, France }\end{array}$ & Brown, fine mud & P. Gayral \\
\hline GH-I & M. tractuosa & Penang, Malaysia & Brown, silty sand & Ong Kah Sin \\
\hline GH-2 & M. tractuosa & Penang, Malaysia & Brown, silty sand & Ong Kah Sin \\
\hline HI-1 5 & M. tractuosa & Auke Bay, Alaska & $\begin{array}{l}\text { Under frozen sand, } \\
\text { upper littoral }\end{array}$ & J. Quast, R. Haight \\
\hline $\mathrm{H}-43$ & ${ }^{*}$ M. tractuosa & Nhatrang, Vietnam & Sand & N. Thach \\
\hline JK-II & M. tractuosa & Moreton Bay, Australia & Brown sand & W. Stephenson \\
\hline T-I3 & M. tractuosa & $\begin{array}{l}\text { Muigh Inis, Carna Co., } \\
\text { Galway, Ireland }\end{array}$ & Brown mud & $\begin{array}{l}\text { C. O'hEocha, } \\
\text { M. de Valera }\end{array}$ \\
\hline
\end{tabular}


Table I (cont.)

\begin{tabular}{|c|c|c|c|c|}
\hline Strain & Name & Location & Habitat ${ }^{6}$ & Collected by? \\
\hline SIO-7 & ${ }^{*} M$. sericea & La Jolla, Calif. & $\begin{array}{l}\text { Marine aquarium } \\
\text { outflow }\end{array}$ & R. A. Lewin \\
\hline SIO-9 & M. sericea & La Jolla, Calif. & $\begin{array}{l}\text { Marine aquarium } \\
\text { outflow }\end{array}$ & R. A. Lewin \\
\hline sio-8 & ${ }^{*}$ M. marina & La Jolla, Calif. & $\begin{array}{l}\text { Marine aquarium } \\
\text { outflow }\end{array}$ & R. A. Lewin \\
\hline \multirow[t]{2}{*}{ TV-2 } & ${ }^{*} M$. furvescens & Samoa & Brown sand & M. Wilcox \\
\hline & Saprospira & & & \\
\hline BEG & ${ }^{*} S$. thermalis & Kotlafjørdur, Iceland & Hot spring & R. A. Lewin \\
\hline CR-123 & S. thermalis & San José, Costa Rica & Rivulet, university & R. A. Lewin \\
\hline CR-125 & S. thermalis & San José, Costa Rica & Rivulet, university & R. A. Lewin \\
\hline$A-I$ & ${ }^{*} S$. toviformis & Campbell's Bay, N.Z. & Sand at tidepool edge & V. Cassie \\
\hline wH & ${ }^{*} S$. grandis & Woods Hole, Mass. & $\begin{array}{l}\text { Rockpool, upper } \\
\text { littoral }\end{array}$ & R. A. Lewin \\
\hline PA-I & S. grandis & Port Aransas, Texas & Decaying algae & C. H. Oppenheimer \\
\hline $\mathrm{PA}-2$ & S. grandis & Port Aransas, Texas & Decaying algae & C. H. Oppenheim \\
\hline PA-3 & S. grandis & Port Aransas, Texas & Decaying algae & C. H. Oppenheimer \\
\hline LJA & S. grandis & La Jolla, Calif. & Eggs of Dendraster & D. Mazia \\
\hline E-I & S. grandis & Ensenada, B.C., Mexico & Mud & R. A. Lewin \\
\hline E-2 & S. grandis & Ensenada, B.C., Mexico & Mud & R. A. Lewin \\
\hline M-I & S. grandis & Mazatlán, Sin., Mexico & Mud & R. A. Lewin \\
\hline$M-2$ & S. grandis & Mazatlán, Sin., Mexico & Mud & R. A. Lewin \\
\hline ROB & S. grandis & Robles, Costa Rica & Mud & R. A. Lewin \\
\hline SG-I & S. grandis & Golfito, Costa Rica & Mud & R. A. Lewin \\
\hline SG-2 & S. grandis & Golfito, Costa Rica & Mud & R. A. Lewin \\
\hline DAW-I & S. grandis & Galápagos Island & Mud among mangroves & E. Y. Dawson \\
\hline DAW-2 & S. grandis & Galápagos Island & Mud among mangroves & E. Y. Dawson \\
\hline DUB-2 & S. grandis & Dubrovnik, Yugoslavia & Mud & R. A. Lewin ${ }^{10}$ \\
\hline DUB-3 & S. grandis & Dubrovnik, Yugoslavia & Mud & R. A. Lewin ${ }^{10}$ \\
\hline $\mathrm{A}-2$ & S. grandis & Castor Bay, N.Z. & Sand & V. Cassie \\
\hline$A-3$ & S. grandis & Castor Bay, N.Z. & Sand, mid-littoral & V. Cassie \\
\hline $\mathrm{L}-\mathrm{I}$ & S. grandis & Kailua, Hawaii & $\begin{array}{l}\text { White sand with green } \\
\text { algae }\end{array}$ & R. W. Grigg \\
\hline
\end{tabular}


Tables 2-6

Specific names are those proposed by Lewin (1969b).

Column headings and other explanatory notes

(I) GC\% Molar \% guanine + cytosine in DNA, determined by $\mathrm{CsCl}$ density-gradient method.

(2) Leng. Length of most cells or filaments in active culture, in $\mu \mathrm{m}$. In many strains, the lengths were very variable, considerably influenced by such factors as shaking, aeration, and age of culture.

(3) Rhap. Rhapidosomes detected in lysate of old culture. A minus sign does not absolutely preclude the possibility of their being present in another lysate of the same strain.

(4) Pig. Pigment type; here Arabic replace Roman numerals (see Table 7). Figs. 7 and 8 illustrate I-dimensional chromatograms of crude pigment extracts from representative types, on different qualities of paper and with different solvent systems (as suggested by Dr S. L. Jensen-personal communication).

(5) Pen. Negative $\log _{10}$ of highest concentration of penicillin permitting growth.

(6) NaLS Growth in sodium lauryl sulphate (100 mg./l.).

(7) Sal. Salinities permitting growth; $F=$ freshwater medium, $\frac{1}{2} S$, i $S, 2 S=$ half, normal, double-strength sea-water media, respectively.

(8) Temp. Highest temperature (tested in $5^{\circ}$ steps) permitting growth.

(9) $+3^{\circ}$. Survival for I week at $+3^{\circ}$.

(10) $-196^{\circ}$ Survival for $2 \mathrm{hr}$ in liquid nitrogen.

(I ) CMC Depolymerization of Na carboxymethyl cellulose $(3 \%)$.

(12) Star. Digestion of $\operatorname{starch}(2 \%)$.

(13) Agar Liquefaction or softening of agar (I \%).

(14) Algin Liquefaction of $\mathrm{K}$ alginate (3\%).

(15) Gel. Liquefaction of gelatin (10\%).

(16) Lit-Mil. Reactions in media containing milk and litmus: $\mathrm{C}=$ clotting, $\mathrm{R}=$ reduction of dye (varied with age of culture), $\mathrm{A}=$ acidification (litmus turned pink: varied with age of culture), $\mathrm{P}=$ proteolysis (redigestion of curd).

(17) Cat. Catalase activity (effervescence with $\mathrm{H}_{2} \mathrm{O}_{2}$ ).

(18) $\mathrm{H}_{2} \mathrm{~S} \quad$ Evolution of $\mathrm{H}_{2} \mathrm{~S}$ (darkening of lead-acetate paper).

(19) Tyr. Growth (+ or - ) and degradation of tyrosine ( $5 \mathrm{~g} . / 1$.): $\mathrm{C}=$ clearing (dissolution of crystals), $\mathrm{R}=$ red or pink halo, $\mathrm{B}=$ black or grey halo.

(20) DOPA Growth (+ or - ) and degradation of dihydroxyphenyl alanine: $\mathrm{C}=$ clearing, $\mathrm{D}=$ black or grey halo.

(2I) Nit. Reduction of nitrate (formation of nitrite); results not always reproducible.

(22) Carbon sources apparently stimulating growth, when present at indicated concentrations of 5.0 or $1.0 \mathrm{~g} . / 1$; results not always reproducible (cf. Dworkin, I966; Mayer, 1967). A dash indicates no perceptible stimulation over control. Ace. $=\mathrm{Na}$ acetate, Lac. $=\mathrm{Na}$ lactate, Gly.= glycerol, Glu. = glucose, Gal. = galactose, Suc. $=$ sucrose .

(23) Nitrogen sources permitting growth, each at a concentration of $1.0 \mathrm{~g} . / \mathrm{l}$.: Tryp. $=$ Tryptone, $\mathrm{CAA}=$ Casamino acids, Glut. $=\mathrm{Na}$ glutamate, $\mathrm{NO}_{3}{ }^{-}=\mathrm{K}$ nitrate.

(24) L-Amino acids essential for growth: $A=$ arginine, $A s=$ aspartic acid, $\mathbf{G}=$ glycine, $\mathrm{H}=$ histidine, $\mathrm{I}=$ isoleucine, $\mathrm{L}=$ leucine, $\mathrm{Ly}=$ lysine, $\mathrm{M}=$ methionine, $\mathrm{P}=$ phenylalanine or tyrosine, $\mathrm{T}=$ threonine, $\mathrm{Tr}=$ tryptophan, $\mathrm{V}=$ valine.

(25) Vit. Vitamins essential for growth: $\mathrm{T}=$ thiamine, $\mathrm{C}=$ cobalamin. Experiments to demonstrate a requirement for cobalamin were not always reproducible, possibly because of contamination of glassware or of the distilled water used for nutrient media, or perhaps because of adaptation to vitamin independence. In the table (c) indicates that, in at least some experiments, cobalamin appeared to be essential for growth.

(26) Nuc. Some unidentified factor, present in hydrolysates of yeast nucleic acid, required for growth. 
Tables 2a,b,c. Cytophaga species: experimental data for all strains

For explanation of columns I-26 see p. I6I.

Table $2 a$.

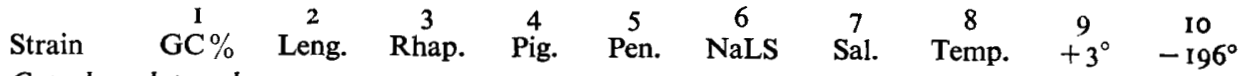
Cytophaga latercula

\begin{tabular}{|c|c|c|c|c|c|c|c|c|c|c|}
\hline SIO-I & $34 \cdot 5$ & 5 & - & 6 & 7 & - & I $\mathrm{S}$ & 30 & + & + \\
\hline \multicolumn{11}{|l|}{ C. lytica } \\
\hline B-9 & $33 \cdot 5$ & $>10$ & - & 4 & 6 & - & $\frac{1}{2}-2 S$ & 30 & + & + \\
\hline WFB-2I & $34 \cdot 5$ & $>15$ & - & 4 & . & . & $\mathrm{F}-2 \mathrm{~S}$ & 40 & + & + \\
\hline BON & $33 \cdot 5^{*}$ & $>10$ & - & 4 & - & . & $\frac{1}{2}-2 S$ & 35 & + & + \\
\hline ENS & 34 & $>10$ & & 4 & 6 & - & $\frac{1}{2}-2 S$ & 40 & + & + \\
\hline LIM-2I & 34 & $>20$ & + & 4 & 6 & - & $\frac{1}{2}-2 S$ & 35 & + & + \\
\hline \multicolumn{11}{|c|}{ C. diffluens (?) } \\
\hline DD-I & 35 & $>20$ & + & 3 & 7 & - & $\frac{1}{2}-2 S$ & 30 & + & + \\
\hline \multicolumn{11}{|c|}{ C. diffluens var. aprica } \\
\hline DUB-4 & 37 & $>50$ & - & 3 & 7 & + & $\frac{1}{2}-2 S$ & 30 & - & + \\
\hline ST-I & $36 \cdot 5$ & $>$ I5 & - & 3 & 6 & + & $\frac{1}{2}-1 S$ & 35 & + & • \\
\hline $\mathrm{JL}-4$ & $35 \cdot 5$ & $>30$ & + & 3 & 6 & + & $\frac{1}{2}-2 S$ & 35 & - & . \\
\hline \multicolumn{11}{|c|}{ C. diffluens var. carnea } \\
\hline Q-1 & $37 \cdot 5$ & $>30$ & - & 3 & . & - & $\frac{1}{2}-2 S$ & 30 & + & + \\
\hline \multicolumn{11}{|l|}{ C. diffluens } \\
\hline Y-I & $4 \mathrm{I}$ & $5-40$ & - & 3 & 6 & - & $\frac{1}{2}-2 S$ & 30 & + & + \\
\hline GOL-I 2 & $4 I$ & $5-10$ & + & 3 & 6 & - & $\frac{1}{2}-2 S$ & 30 & + & + \\
\hline $\mathrm{N}-3$ & $4 I$ & $>20$ & - & 3 & . & - & $\frac{1}{2}-2 S$ & 30 & + & + \\
\hline $\mathrm{NN}-3$ & 40 & $>20$ & - & 3 & 7 & - & $\frac{1}{2}-2 S$ & 35 & - & + \\
\hline B-I & 42 & $>10$ & - & 3 & 7 & - & $\frac{1}{2}-2 S$ & 40 & + & + \\
\hline LIM-I & 43 & $>30$ & - & 3 & 6 & - & $\frac{1}{2}-2 S$ & 30 & - & + \\
\hline $0-2$ & 42 & $>10$ & + & 3 & 7 & - & $\frac{1}{2}-2 S$ & 35 & + & + \\
\hline
\end{tabular}

Table $2 b$.

$\begin{array}{cccccccccccc} & \text { II } & \text { I2 } & \text { I3 } & \text { I4 } & \text { I5 } & \text { I6 } & 17 & \text { I8 } & \text { I9 } & 20 & 2 \text { I } \\ \text { Strain } & \text { CMC } & \text { Star. } & \text { Agar } & \text { Algin } & \text { Gel. } & \text { Lit-Mil. } & \text { Cat. } & \mathrm{H}_{2} \mathrm{~S} & \text { Tyr. } & \text { DOPA } & \text { Nit. }\end{array}$ Cytophaga latercula

\begin{tabular}{|c|c|c|c|c|c|c|c|c|c|c|c|}
\hline SIO-I & + & - & + & + & + & $+\mathrm{CRA}$ & - & + & $+\mathrm{C}$ & - & - \\
\hline \multicolumn{2}{|l|}{ C. lytica } & + & + & + & + & $+\mathrm{CPR}$ & + & - & + RO & $+\mathrm{DC}$ & - \\
\hline WFB-21 & + & + & + & + & + & $+\mathrm{CR}$ & + & + & $+\mathrm{RC}$ & + & - \\
\hline BON & + & + & + & + & & $+\mathrm{CR}$ & + & - & $+\mathrm{RC}$ & + & - \\
\hline ENS & + & + & + & + & + & $+\mathrm{CR}$ & + & - & $+\mathrm{RC}$ & + & - \\
\hline LIM-2I & + & + & + & + & + & $+\mathrm{CR}$ & + & + & + RO & $+\mathrm{DC}$ & - \\
\hline \multicolumn{12}{|c|}{ C. diffluens (?) } \\
\hline DD-I & + & + & + & + & + & $+\mathrm{RA}$ & - & + & + & $+\mathrm{C}$ & - \\
\hline \multicolumn{12}{|c|}{ C. diffluens var. aprica } \\
\hline DUB-4 & + & + & + & + & + & + CRA & - & + & + & - & - \\
\hline ST-I & + & + & + & + & + & + CRA & - & + & + & + & + \\
\hline JL-4 & + & + & + & + & + & $+\mathrm{RA}$ & - & + & + & - & - \\
\hline \multicolumn{12}{|c|}{ C. diffluens var. carnea } \\
\hline Q-I & + & - & + & + & + & - & - & - & + & - & + \\
\hline \multicolumn{12}{|c|}{ C. diffluens } \\
\hline Y-I & + & + & + & + & + & + CRA & - & - & + & $+\mathrm{C}$ & - \\
\hline GOL-12 & + & + & + & + & + & & - & - & + & - & + \\
\hline $\mathrm{N}-3$ & + & + & + & + & + & + CRA & - & + & $+(\mathrm{R})$ & $+\mathrm{C}$ & + \\
\hline $\mathrm{NN}-3$ & + & + & + & + & + & $+\mathrm{RA}$ & - & + & + & $+\mathrm{C}$ & - \\
\hline B-I & + & + & + & + & + & + CRA & - & + & + & $+\mathrm{C}$ & - \\
\hline LIM-I & + & + & + & + & + & $+\mathrm{CR}$ & - & + & + & - & - \\
\hline $0-2$ & + & + & + & + & + & +CPRA & - & + & + & $+\mathrm{C}$ & + \\
\hline
\end{tabular}


Table $2 c$.

22

$\overbrace{\overbrace{\text { tial }}^{23}}^{23} \begin{array}{cc}24 \\ \text { Essen- }\end{array} 25$

Strain Ace. Lac. Gly. Glu. Gal. Suc. Tryp. CAA Glut. $\mathrm{NO}_{3}^{-}$AAs Vit. Nuc.

Cytophaga latercula

\begin{tabular}{|c|c|c|c|c|c|c|c|c|c|c|c|c|c|}
\hline SIO-I & - & - & - & $5, \mathrm{I}$ & $5, \mathrm{I}$ & $5, \mathrm{I}$ & + & + & + & + & - & - & - \\
\hline \multicolumn{14}{|l|}{ C. lytica } \\
\hline B-9 & $5, \mathrm{I}$ & 5 & $5, \mathrm{I}$ & - & - & - & + & + & + & + & - & - & - \\
\hline WFB-2I & - & - & $5, \mathrm{I}$ & $5, \mathrm{I}$ & $5, \mathrm{I}$ & 5,1 & + & + & t & + & - & - & - \\
\hline BON & - & - & $5, \mathrm{I}$ & 5,1 & $5, \mathrm{I}$ & $5, \mathrm{I}$ & + & + & t & + & - & - & - \\
\hline ENS & - & - & $5, \mathrm{I}$ & $5, \mathrm{I}$ & 5,1 & 5,1 & + & + & + & + & - & - & - \\
\hline LIM-2 I & $5, \mathrm{I}$ & $5, \mathrm{I}$ & $5, \mathrm{I}$ & $5, \mathrm{I}$ & $5, \mathrm{I}$ & $5, \mathrm{I}$ & + & + & + & - & - & - & - \\
\hline \multicolumn{14}{|c|}{ C. diffluens (?) } \\
\hline DD-I & - & - & - & - & I & - & + & + & . & . & . & . & - \\
\hline \multicolumn{14}{|c|}{ C. diffluens var. aprica } \\
\hline DUB-4 & $5, \mathrm{I}$ & - & - & I & $5, \mathrm{I}$ & - & + & . & . & . & . & . & - \\
\hline ST-I & $5, \mathrm{I}$ & - & - & I & $5, \mathrm{I}$ & $5, \mathrm{I}$ & + & + & . & . & . & . & - \\
\hline $\mathrm{JL}-4$ & I & - & 5 & - & - & 5 & + & + & + & - & - & - & - \\
\hline \multicolumn{14}{|c|}{ C. diffluens var. carnea } \\
\hline$Q-I$ & - & - & - & - & - & , I & + & + & + & $\perp$ & - & . & - \\
\hline \multicolumn{14}{|c|}{ C. diffluens } \\
\hline$Y-I$ & I & - & - & - & $5, \mathrm{I}$ & - & + & + & . & & . & . & - \\
\hline GOL-I 2 & $5, \mathrm{I}$ & - & - & - & - & - & + & . & . & & . & . & - \\
\hline $\mathrm{N}-3$ & - & - & - & - & I & - & + & . & . & & . & . & - \\
\hline $\mathrm{NN}-3$ & $5, \mathrm{I}$ & - & - & - & - & 5 & + & . & . & & . & . & - \\
\hline B-I & $5, \mathrm{I}$ & - & - & - & I & - & + & + & t & - & - & . & - \\
\hline LIM-I & $5, \mathrm{I}$ & - & - & I & I & $5, \mathrm{I}$ & + & & & . & . & . & - \\
\hline $0-2$ & $5, \mathrm{I}$ & - & - & $5, \mathrm{I}$ & I & 5 & + & + & + & + & - & - & - \\
\hline
\end{tabular}


Tables $3 a, b, c$. Flexibacter species: experimental data for all strains

For explanations of columns $1-26$, see p. I6r.

\section{Table $3 a$.}

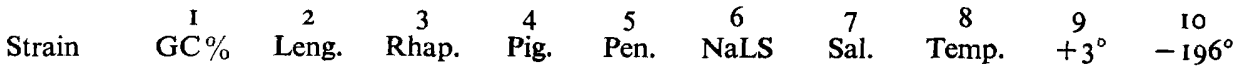
Flexibacter litoralis

\begin{tabular}{|c|c|c|c|c|c|c|c|c|c|c|}
\hline SIO-4 & $3 I$ & $>180$ & - & I & 6 & - & $\frac{1}{2}-2 S$ & 30 & + & + \\
\hline \multicolumn{11}{|c|}{ F. aurantiacus } \\
\hline Dwo & $31 \cdot 5$ & $5-20$ & - & 5 & 6 & + & F-I S & 30 & + & + \\
\hline PSY & 32 & $5-20$ & - & 5 & 6 & + & $\mathbf{F}$ & 30 & + & + \\
\hline \multicolumn{11}{|c|}{ F. aurantiacus var. copepodarum } \\
\hline $\mathrm{COP}$ & 33 & 5 & - & 4 & 6 & - & I $\mathbf{S}$ & 30 & + & - \\
\hline \multicolumn{11}{|c|}{ F. giganteus } \\
\hline CR-103 & 32 & $>50$ & - & 2 & 9 & - & $\mathbf{F}$ & 35 & - & - \\
\hline CR-104 & 32 & $>50$ & - & 2 & 8 & - & $\mathrm{F}$ & 35 & - & - \\
\hline CR-1 24 & 32 & $>50$ & - & 2 & 9 & - & $\mathrm{F}$ & 30 & - & - \\
\hline \multicolumn{11}{|c|}{ F. aurantiacus var. excathedrus } \\
\hline CR-134 & $34 \cdot 5$ & 10 & - & 4 & 7 & - & $\mathrm{F}$ & 40 & + & + \\
\hline \multicolumn{11}{|c|}{$F$. roseolus } \\
\hline CR-I 4I & $34 \cdot 5$ & $>50$ & - & $I$ & 9 & - & $F-2 S$ & 40 & + & + \\
\hline CR-I 55 & 38 & $>50$ & - & I & 9 & - & $\mathrm{F}-\mathrm{I} S$ & 40 & + & + \\
\hline \multicolumn{11}{|l|}{ F. ruber } \\
\hline GEY & 37 & $>50$ & - & I & 8 & - & $\mathbf{F}$ & 40 & + & + \\
\hline \multicolumn{11}{|c|}{ F. flexilis var. pelliculosus } \\
\hline FLE & $39 \cdot 5$ & $10-30$ & $\rightarrow$ & 3 & 6 & - & $\mathrm{F}$ & 35 & + & + \\
\hline \multicolumn{11}{|l|}{ F. flexilis } \\
\hline CR-63 & 41 & $10-50$ & 一 & 3 & 6 & - & $\mathbf{F}$ & 40 & + & + \\
\hline CR-8I & 43 & $10-50$ & - & 3 & 8 & - & $\mathbf{F}$ & 35 & + & + \\
\hline$A-52$ & 43 & $10-50$ & - & 3 & 6 & - & $\mathrm{F}$ & 40 & + & + \\
\hline WAR-5 & $40 \cdot 5$ & $10-50$ & - & 3 & 6 & - & $\mathbf{F}$ & 40 & + & + \\
\hline \multicolumn{11}{|c|}{ F. flexilis var. iolanthae } \\
\hline BA-24 & $4 I \cdot 3$ & $10-30$ & - & 3 & 6 & - & $\mathrm{F}$ & 35 & - & - \\
\hline \multicolumn{11}{|l|}{ F. sancti } \\
\hline BA-3 & 46 & $5-15$ & - & 4 & 7 & - & $\mathrm{F}$ & 35 & + & - \\
\hline $\mathrm{BA}-23$ & 47 & $5-15$ & - & 4 & 6 & - & $\mathrm{F}$ & 35 & + & + \\
\hline MIC & $46 \cdot 5$ & $10-50$ & - & 4 & 6 & - & $\mathbf{F}$ & 35 & + & + \\
\hline \multicolumn{11}{|l|}{ F. elegans } \\
\hline NZ-I & $47 \cdot 5$ & $>50$ & - & 3 & 8 & - & F-I S & 40 & + & + \\
\hline
\end{tabular}


Table $3 b$.

\begin{tabular}{|c|c|c|c|c|c|c|c|c|c|c|c|}
\hline Strain & $\stackrel{\text { I I }}{\text { CMC }}$ & $\begin{array}{c}\text { I } 2 \\
\text { Star. }\end{array}$ & $\begin{array}{c}\text { I3 } \\
\text { Agar }\end{array}$ & $\begin{array}{c}\text { I4 } \\
\text { Algin }\end{array}$ & $\begin{array}{l}\text { I } 5 \\
\text { Gel. }\end{array}$ & $\begin{array}{c}16 \\
\text { Lit-Mil. }\end{array}$ & $\begin{array}{c}17 \\
\text { Cat. }\end{array}$ & $\begin{array}{c}\mathrm{I} 8 \\
\mathrm{H}_{2} \mathrm{~S}\end{array}$ & $\begin{array}{l}\text { I9 } \\
\text { Tyr. }\end{array}$ & $\stackrel{20}{\text { DOPA }}$ & $\begin{array}{c}21 \\
\text { Nit. }\end{array}$ \\
\hline \multicolumn{12}{|c|}{ Flexibacter litoralis } \\
\hline SIO-4 & - & + & - & - & + & $+\mathrm{C}$ & - & - & $+\mathrm{RC}$ & - & - \\
\hline \multicolumn{12}{|c|}{ F. aurantiacus } \\
\hline Dwo & + & + & - & - & + & $+\mathbf{R}$ & + & - & $+\mathrm{C}$ & $+\mathrm{C}$ & 一 \\
\hline PSY & + & - & - & - & + & + & + & - & $+\mathrm{C}$ & $+\mathrm{C}$ & - \\
\hline \multicolumn{12}{|c|}{ F. aurantiacus var. copepodarum } \\
\hline COP & - & - & - & - & + & $+\mathrm{CA}$ & - & - & $+\mathrm{C}$ & - & - \\
\hline \multicolumn{12}{|c|}{ F. giganteus } \\
\hline CR-IO3 & - & + & - & - & + & $+\mathrm{CP}$ & - & + & \pm & - & - \\
\hline CR-IO4 & - & + & - & - & + & + & - & + & \pm & - & - \\
\hline CR-I 24 & - & + & - & - & + & + & - & - & \pm & - & 一 \\
\hline \multicolumn{12}{|c|}{ F. aurantiacus var. excathedrus } \\
\hline CR-134 & - & + & - & - & + & $+\mathrm{CPR}$ & - & - & $+\mathrm{BC}$ & $+\mathrm{DC}$ & - \\
\hline \multicolumn{12}{|c|}{ F. roseolus } \\
\hline CR-I4I & - & - & - & - & + & + & - & - & - & - & - \\
\hline CR-I 55 & - & - & - & - & + & + & - & - & - & - & - \\
\hline \multicolumn{12}{|l|}{ F. ruber } \\
\hline GEY & - & + & - & - & + & + & - & - & \pm & - & + \\
\hline \multicolumn{12}{|c|}{ F. flexilis var. pelliculosus } \\
\hline FLE & + & + & - & - & + & $+\mathbf{R}$ & - & + & $+\mathrm{R}$ & $+\mathrm{DC}$ & + \\
\hline \multicolumn{12}{|l|}{ F. flexilis } \\
\hline CR-63 & - & - & - & - & + & $+\mathbf{R}$ & 一 & + & + & + & - \\
\hline CR-8I & - & - & - & - & + & $+\mathbf{R}$ & - & + & + & + & - \\
\hline$A-52$ & - & + & - & - & + & $+\mathbf{R}$ & - & + & + & + & - \\
\hline WAR-5 & - & - & - & - & + & $+\mathrm{R}$ & - & + & + & + & - \\
\hline \multicolumn{12}{|c|}{ F. flexilis var. iolanthae } \\
\hline BA-24 & - & - & - & - & + & + & - & $\rightarrow$ & + & + & - \\
\hline \multicolumn{12}{|l|}{$F$. sancti } \\
\hline BA-3 & + & + & - & - & + & $+\mathrm{AR}$ & - & - & $+\mathrm{C}$ & + & + \\
\hline $\mathrm{BA}-23$ & + & - & - & - & + & + & - & - & $+\mathrm{C}$ & + & + \\
\hline MIC & + & + & - & - & + & $+\mathbf{R}$ & - & + & $+\mathrm{C}$ & $+\mathrm{DC}$ & - \\
\hline \multicolumn{12}{|l|}{ F.elegans } \\
\hline $\mathrm{NZ}-\mathrm{I}$ & - & - & - & - & + & + & - & - & $+\mathrm{C}$ & + & - \\
\hline
\end{tabular}


Table $3 c$.

22

23

24

$25 \quad 26$

Strain Ace. Lac. Gly. Glu. Gal. Suc. Tryp. CAA Glut. $\mathrm{NO}_{3}^{-}$Essential AAs Vit. Nuc.

Flexibacter litoralis

sIo-4

F. aurantiacus

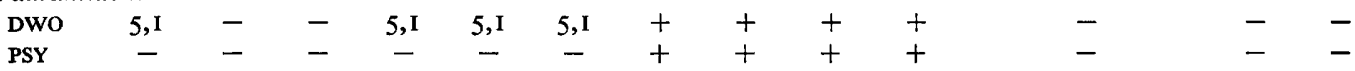

F. aurantiacus var. copepodarum

COP

F. giganteus

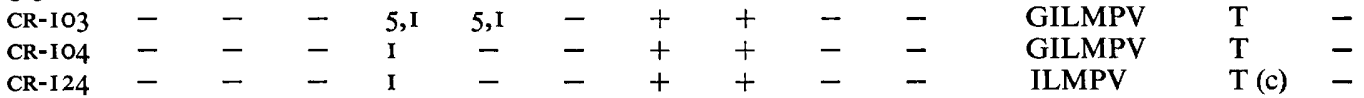

F. aurantiacus var. excathedrus

CR-134

$F$, roseolus

$\begin{array}{lllllllllll}\text { CR-I4I } & 5 & - & - & - & - & - & + & + & - & - \\ \text { CR-I55 } & - & \text { I } & - & - & - & - & + & + & - & -\end{array}$

$\begin{array}{cl}\text { AILMPTV } & \text { T } \\ \text { AGILMPTV } & \text { T (c) }\end{array}$

F. ruber

GEY 5,I 5,I $-5, \mathrm{I} \quad 5, \mathrm{I} \quad 5, \mathrm{I}+{ }^{+}+$

T

F. flexilis var. pelliculosus FLE

$5, \mathrm{I} 5, \mathrm{I} 5, \mathrm{I}+++$

F. flexilis

$\begin{array}{lllllllll}\mathrm{CR}-63 & - & - & - & - & - & 5, \mathrm{I} & + & +\end{array}-$

$\begin{array}{lllllllllll}\mathrm{CR}-8 \mathrm{I} & - & - & - & - & - & 5, \mathrm{I} & + & + & - & - \\ \mathrm{A}-52 & 5, \mathrm{I} & - & - & 5, \mathrm{I} & - & 5, \mathrm{I} & + & + & - & -\end{array}$

WAR-5 - $\quad-\quad 5, \mathrm{I}$ 5,I $5, \mathrm{I}+{ }^{2}+-$

$\begin{array}{lll}\text { AILMTV } & \text { T } & - \\ \text { AILMTV } & \text { T } & - \\ \text { AILMTV } & \text { T } & - \\ \text { AILMTV } & \text { T } & -\end{array}$

F. flexilis var. iolanthae

BA-24 5

F. sancti

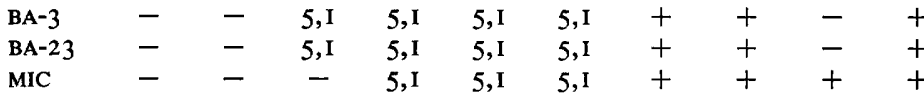

F. elegans

NZ-I 
Tables $4 a, b, c$. Microscilla species and Flexithrix dorotheae, experimental data for all strains

For explanations of columns I-26, see p. I6I.

Table $4 a$.

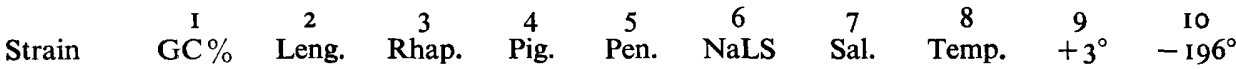
Microscilla arenaria

\begin{tabular}{|c|c|c|c|c|c|c|c|c|c|c|}
\hline $\mathrm{HJ}-\mathrm{I}$ & $32 \cdot 5$ & $>20$ & - & 3 & 7 & - & $\frac{1}{2}-2 S$ & 30 & - & + \\
\hline \multicolumn{11}{|c|}{ M. aggregans var. catalatica } \\
\hline $\mathrm{HI}-3$ & 35 & $>20$ & - & 4 & 6 & - & $\frac{1}{2}-2 S$ & 30 & + & + \\
\hline \multicolumn{11}{|c|}{ M. aggregans } \\
\hline$Q-3$ & $4 I \cdot 5$ & $>100$ & - & 4 & 6 & - & $\frac{1}{2}-2 S$ & 40 & + & + \\
\hline QQ-I & $39 \cdot 5$ & $>30$ & - & 4 & 6 & - & $\frac{1}{2}-2 S$ & 40 & + & + \\
\hline QQ-I I & $40 \cdot 5$ & $>30$ & . & 4 & 6 & - & $\frac{1}{2}-2 S$ & 35 & + & + \\
\hline JL-I 3 & $36 \cdot 5$ & $>20$ & - & 4 & 8 & - & $\frac{1}{2}-2 S$ & 40 & + & + \\
\hline $\mathrm{NN}-\mathrm{I} 3$ & $36 \cdot 5$ & $>70$ & - & 4 & 6 & - & $\frac{1}{2}-2 S$ & 40 & + & + \\
\hline \multicolumn{11}{|c|}{ M. tractuosa } \\
\hline EE-I 3 & $39 \cdot 5$ & $>15$ & - & 3 & 7 & - & $\mathrm{F}-2 \mathrm{~S}$ & 35 & + & + \\
\hline EG-I 3 & 37 & $>40$ & + & 3 & 7 & - & $\frac{1}{2}-2 S$ & 30 & + & + \\
\hline GH-I & 34.5 & $>50$ & - & 3 & 6 & + & $\frac{1}{2}-2 S$ & 40 & + & + \\
\hline GH-2 & $35 \cdot 5$ & $>50$ & - & 3 & 7 & - & $\frac{1}{2}-2 S$ & 40 & + & + \\
\hline HI- 15 & 36 & $5-10$ & - & 3 & . & - & F-2 S & - & + & . \\
\hline H-43 & $36 \cdot 5$ & $>$ I5 & - & 3 & 7 & - & $F-2 S$ & 35 & + & + \\
\hline JK-I I & 37 & $>20$ & 一 & 3 & 7 & - & $F-2 S$ & 30 & + & + \\
\hline$T-13$ & 38 & $>10$ & - & 3 & 7 & - & $\mathrm{F} \rightarrow 2 \mathrm{~S}$ & 30 & + & + \\
\hline \multicolumn{11}{|c|}{ M. sericea } \\
\hline SIO-7 & 39 & $>30$ & - & 3 & . & - & $\frac{1}{2}-2 S$ & 30 & + & + \\
\hline SIO-9 & 38 & $>100$ & + & 3 & 7 & - & $\frac{1}{2}-2 S$ & 30 & - & + \\
\hline \multicolumn{11}{|c|}{ M. marina } \\
\hline SIO-8 & 42 & $>150$ & + & 3 & 6 & - & $I-2 S$ & 30 & + & + \\
\hline \multicolumn{11}{|c|}{ M. furvescens } \\
\hline TV-2 & 44 & $10-50$ & - & 3 & . & - & . & - & + & + \\
\hline
\end{tabular}

Table $4 b$.

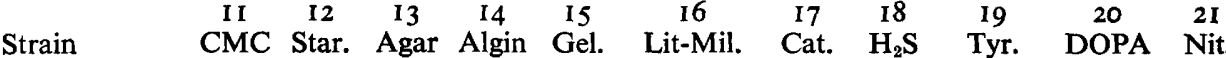
Microscilla arenaria

HJ-I $+\quad+\quad+\quad+$ RA $-++t+$

M. aggregans var. catalatica

HI-3

M. aggregans

Q-3

QQ-I

QQ-I I

JL-I 3

$\mathrm{NN}-\mathrm{I} 3$

M. tractuosa

EE-1 3

EG-I3

GH-I

GH-2

HI-I 5

$\mathrm{H}-43$

$\mathrm{JK}-\mathrm{I}$

T-I 3

$M$. sericea

SIO-7

sio-9

M. marina

SIO-8

M. furvescens TV-2

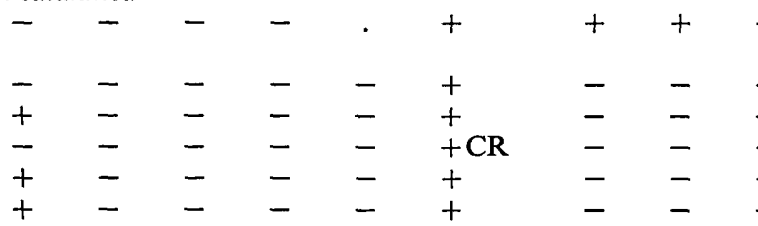

$$
\begin{array}{lllll}
- & - & - & - & + \\
- & + & - & - & + \\
- & + & - & - & + \\
- & + & - & - & + \\
- & + & - & - & + \\
- & + & - & - & + \\
- & - & - & - & - \\
- & - & - & - & +
\end{array}
$$$$
\begin{array}{llll}
+\mathrm{CR} & - & + & + \\
+\mathrm{CR} & - & - & + \\
+\mathrm{CPR} & - & - & + \\
+\mathrm{R} & - & + & + \\
+\mathrm{CR} & - & + & + \\
+\mathrm{CPRA} & - & - & + \\
+\mathrm{CR} & - & - & + \\
+\mathrm{CPR} & - & + & +
\end{array}
$$$$
+\mathrm{R}
$$$$
\begin{array}{lll}
- & + & - \\
- & +
\end{array}
$$$$
\text { - }+
$$$$
\text { - }
$$$$
+
$$$$
+\mathrm{C}
$$$$
-\quad
$$

$\begin{array}{lll}+ & + \\ - & +\end{array}$ 
Table $4 c$.

22

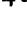

23

$24 \quad 25 \quad 26$

Essen-

tial

Strain Ace. Lac. Gly. Glu. Gal. Suc. Tryp. CAA Glut. $\mathrm{NO}_{3}^{-}$AAs Vit. Nuc. Microscilla arenaria

\begin{tabular}{|c|c|c|c|c|c|c|c|c|c|c|c|c|c|}
\hline $\mathrm{HJ}-\mathrm{I}$ & $\mathbf{I}$ & I & - & $5, \mathrm{I}$ & 5,1 & 5 & + & + & . & . & . & . & - \\
\hline \multicolumn{14}{|c|}{ M. aggregans var. catalatica } \\
\hline $\mathrm{HI}-3$ & - & - & - & - & - & - & + & - & - & - & - & . & - \\
\hline \multicolumn{14}{|c|}{ M. aggregans } \\
\hline Q-3 & - & - & - & 5,1 & $5, \mathrm{I}$ & $5, I$ & + & + & + & + & - & . & - \\
\hline QQ-I & $5, \mathrm{I}$ & 5,1 & $5, \mathrm{I}$ & 5,1 & $5, \mathrm{I}$ & $5, \mathrm{I}$ & + & + & + & + & - & - & - \\
\hline QQ-I I & - & - & - & $5, \mathrm{I}$ & $5, \mathrm{I}$ & $5, \mathrm{I}$ & + & + & + & - & - & . & - \\
\hline JL-I 3 & - & - & - & $5, \mathrm{I}$ & $5, \mathrm{I}$ & $5, \mathrm{I}$ & + & + & + & + & - & - & - \\
\hline NN-I 3 & - & - & - & $5, \mathrm{I}$ & 5,1 & $5, \mathrm{I}$ & + & + & + & - & - & - & - \\
\hline \multicolumn{14}{|c|}{ M. tractuosa } \\
\hline EE-I 3 & - & - & - & $5, \mathrm{I}$ & - & - & + & . & . & . & . & . & - \\
\hline EG-I 3 & - & - & - & $5, \mathrm{I}$ & - & 5,1 & + & . & . & . & . & . & - \\
\hline GH-I & - & - & - & $5, \mathrm{I}$ & 5 & - & + & + & . & - & . & . & - \\
\hline GH-2 & I & - & - & $\mathbf{I}$ & 5 & - & + & + & . & . & - & - & - \\
\hline $\mathrm{HI}-\mathrm{I} 5$ & - & - & - & . & - & - & + & + & + & - & - & - & - \\
\hline $\mathrm{H}-43$ & - & - & $5, \mathrm{I}$ & $5, \mathrm{I}$ & $5, \mathrm{I}$ & 5,1 & + & + & . & $\cdot$ & $\cdot$ & . & - \\
\hline JK-I I & - & - & $5, \mathrm{I}$ & $5, I$ & I & - & + & + & . & . & . & . & - \\
\hline$T-13$ & - & - & $5, \mathrm{I}$ & $5, \mathrm{I}$ & 5 & $5, \mathrm{I}$ & + & + & . & . & . & . & - \\
\hline \multicolumn{14}{|c|}{ M. sericea } \\
\hline SIO-7 & - & - & $5, \mathrm{I}$ & $5, \mathrm{I}$ & $5, \mathrm{I}$ & 5,1 & + & - & - & - & . & . & - \\
\hline SIO-9 & - & - & - & - & - & $5, \mathrm{I}$ & + & - & - & - & - & . & - \\
\hline \multicolumn{14}{|c|}{ M. marina } \\
\hline SIO-8 & - & 5 & - & - & - & - & + & \pm & - & - & . & . & - \\
\hline \multicolumn{14}{|c|}{ M. furvescens } \\
\hline TV-2 & - & - & - & $5, \mathrm{I}$ & $5, \mathrm{I}$ & $5, \mathrm{I}$ & + & + & + & + & - & - & - \\
\hline
\end{tabular}

Tables 5a,b,c. Saprospira species: experimental data for all strains

For explanations of columns $\mathrm{I}-26$, see p. I6r.

Table $5 a$.

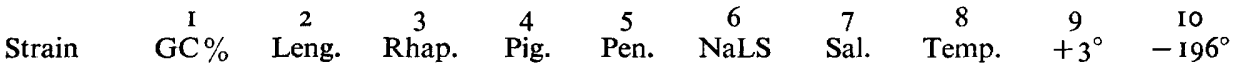
Saprospira thermalis

$\begin{array}{lrrrrrrrrrr}\text { BEG } & 36 \cdot 5 & >50 & - & 2 & 8 & - & F & 40 & - & - \\ \text { CR-123 } & 34.5 & \text { I50 } & - & 2 & 9 & - & \text { F } & 40 & - & - \\ \text { CR-125 } & 37 \cdot 2 & >50 & - & 2 & 9 & - & \text { F } & 40 & - & -\end{array}$

S. toviformis

A-I $38 \quad 10-50+3 a^{*}>9 \quad-\quad F-2 S 30+$

S. grandis

$\begin{array}{lllllllllll}\text { WH } & 47 \cdot 5 & >50 & + & 3 & 8 & - & \frac{1}{2}-2 \mathrm{~S} & 40 & - & - \\ \text { PA-I } & 47 \cdot 5 & >50 & + & 3 & 9 & - & \frac{1}{2}-2 \mathrm{~S} & 40 & + & - \\ \text { PA-2 } & 46 \cdot 5 & >50 & + & 3 & >9 & - & \frac{1}{2}-2 \mathrm{~S} & 40 & - & - \\ \text { PA-3 } & 46 \cdot 5 & >50 & + & 3 & 8 & - & \frac{1}{2}-2 \mathrm{~S} & 35 & - & + \\ \text { LJA } & 46 \cdot 5 & >50 & + & 3 & 9 & - & \frac{1}{2}-2 \mathrm{~S} & 30 & - & + \\ \text { E-I } & 46 \cdot 5 & >50 & + & 3 & 8 & - & \frac{1}{2}-1 \mathrm{~S} & 35 & - & + \\ \text { E-2 } & 48 & >50 & + & 3 & 8 & - & \frac{1}{2}-2 \mathrm{~S} & 40 & - & + \\ \text { M-I } & 48 & >50 & + & 3 & 8 & - & \frac{1}{2}-2 \mathrm{~S} & 40 & - & + \\ \text { M-2 } & 47 \cdot 5 & >50 & + & 3 & 8 & - & \frac{1}{2}-1 \mathrm{~S} & 40 & - & - \\ \text { ROB } & 48 & >50 & + & 3 & 8 & - & \frac{1}{2}-2 \mathrm{~S} & 40 & - & - \\ \text { SG-I } & 47 & >50 & + & 3 & 8 & - & \frac{1}{2}-2 \mathrm{~S} & 40 & - & + \\ \text { SG-2 } & 47 & >50 & + & 3 & 8 & - & \frac{1}{2}-1 \mathrm{~S} & 40 & - & - \\ \text { DAW-I } & 47 \cdot 3 & >50 & + & 3 & 8 & - & \frac{1}{2}-2 \mathrm{~S} & 35 & - & - \\ \text { DAW-2 } & 47 & >50 & + & 3 & >9 & - & 1-2 \mathrm{~S} & 40 & - & + \\ \text { DUB-2 } & 47 & >50 & + & 3 & 8 & - & \frac{1}{2}-2 \mathrm{~S} & 35 & + & - \\ \text { DUB-3 } & 48 & >50 & + & 3 & 9 & - & \frac{1}{2}-2 \mathrm{~S} & 40 & - & - \\ \text { A-2 } & 46 & >50 & + & 3 & 8 & - & \text { F-2 S } & 30 & + & - \\ \text { A-3 } & 46 & >50 & + & 3 & 8 & - & \text { F-2 S } & 40 & + & - \\ \text { JL-I } & 47 \cdot 5 & >50 & + & 3 & 8 & - & \text { F-2 S } & 40 & - & .\end{array}$

* See Table 7. 
Table $5 b$. Saprospira thermalis

\begin{tabular}{|c|c|c|c|c|c|c|c|c|c|c|c|}
\hline BEG & - & + & - & - & + & + & - & + & + & \pm & - \\
\hline CR-I 23 & - & + & - & - & + & + & - & + & + & \pm & - \\
\hline CR-1 25 & - & + & - & - & + & + & - & + & + & \pm & - \\
\hline \multicolumn{12}{|c|}{ S. toviformis } \\
\hline A-I & + & - & - & - & + & $+\mathrm{C}$ & - & - & + & - & - \\
\hline \multicolumn{12}{|l|}{ S. grandis } \\
\hline WH & - & - & - & - & + & $+\mathrm{C}$ & - & - & $+\mathrm{R}$ & - & - \\
\hline PA-I & - & - & - & - & + & $+\mathrm{C}$ & - & - & $+R$ & - & - \\
\hline PA-2 & - & - & - & - & + & $+\mathrm{C}$ & - & - & $+\mathbf{R}$ & - & - \\
\hline $\mathrm{PA}-3$ & - & - & - & - & + & $+\mathrm{C}$ & - & - & $+\mathrm{R}$ & - & - \\
\hline LJA & - & - & - & - & + & $+\mathrm{C}$ & - & - & $+R$ & - & - \\
\hline E-I & - & - & - & - & + & $+\mathrm{C}$ & - & - & $+R$ & - & - \\
\hline $\mathrm{E}-2$ & - & - & - & - & + & $+\mathrm{C}$ & - & - & $+\mathbf{R}$ & - & - \\
\hline$M-I$ & - & - & - & - & + & $+\mathrm{C}$ & - & - & $+\mathrm{R}$ & - & - \\
\hline$M-2$ & - & - & - & - & + & $+\mathrm{C}$ & - & - & $+\mathrm{R}$ & - & - \\
\hline ROB & - & - & - & - & + & $+\mathrm{C}$ & - & - & $+\mathrm{R}$ & - & - \\
\hline SG-I & - & - & - & - & + & $+\mathrm{C}$ & - & - & $+\mathrm{R}$ & - & - \\
\hline SG-2 & - & - & - & - & + & $+\mathrm{C}$ & - & - & $+\mathrm{R}$ & - & - \\
\hline DAW-I & - & - & - & - & + & $+\mathrm{C}$ & - & - & $+\mathrm{R}$ & - & - \\
\hline DAW-2 & - & - & - & - & + & $+\mathrm{C}$ & - & - & $+R$ & - & - \\
\hline DUB-2 & - & - & - & - & + & $+\mathrm{CR}$ & - & - & $+\mathbf{R}$ & - & - \\
\hline DUB-3 & - & - & - & - & + & $+\mathrm{C}$ & - & - & $+R$ & - & - \\
\hline$A-2$ & - & - & - & - & + & $+\mathrm{C}$ & - & - & $+\mathbf{R}$ & - & - \\
\hline A-3 & - & - & - & - & + & $+\mathrm{CR}$ & - & - & $+\mathbf{R}$ & - & - \\
\hline JL-I & - & - & - & - & + & $+\mathrm{CPR}$ & - & - & $+\mathbf{R}$ & - & - \\
\hline
\end{tabular}

Table $5 c$.

22

Strain Ace. Lac. Gly. Glu. Gal. Suc. Tryp. CAA Glut. $\mathrm{NO}_{3}^{-}$Essential AA Saprospira thermalis

\begin{tabular}{|c|c|c|c|c|c|c|c|c|c|c|c|c|}
\hline BEG & - & - & - & 5,1 & - & I & + & + & - & - & ILV & CT \\
\hline CR-I 23 & - & - & - & $5, \mathrm{I}$ & - & . & + & + & - & - & ILV & CT \\
\hline CR-I 25 & - & - & - & $5, \mathrm{I}$ & - & I & + & + & - & - & ILV & CT \\
\hline
\end{tabular}

\section{S. toviformis}

\begin{tabular}{|c|c|c|c|c|c|c|c|c|c|c|c|c|}
\hline$A-I$ & $5, \mathrm{I}$ & $5, \mathrm{I}$ & - & - & - & - & + & + & - & - & AGHILLyMPTV & - \\
\hline \multicolumn{13}{|l|}{ S. grandis } \\
\hline WH & - & - & - & - & - & - & + & - & - & - & AAsHILLyMPTTrV & + \\
\hline PA-I & - & - & - & - & - & - & + & - & - & - & AAsHILLyMPTTrV & + \\
\hline PA-2 & - & - & - & - & - & - & + & - & - & - & AAsHILLyMPTTrV & + \\
\hline PA-3 & - & - & - & - & - & - & + & - & - & - & AAsHILLyMPTTrV & + \\
\hline LJA & - & - & - & - & - & - & + & - & - & - & AAsHILLyMPTTrV & + \\
\hline E-I & - & - & - & - & - & - & + & - & - & - & AAsHILLyMPTTrV & + \\
\hline E-2 & - & - & - & - & - & - & + & - & - & - & AAsHILLyMPTTrV & + \\
\hline M-I & $5, \mathrm{I}$ & - & - & - & - & - & + & - & - & - & AAsHILLyMPTTrV & + \\
\hline M-2 & $5, \mathrm{I}$ & - & - & - & - & - & + & - & - & - & AAsHILLyMPTTrV & + \\
\hline ROB & $5, \mathrm{I}$ & - & - & - & - & - & + & - & - & - & AAsHILLyMPTTrV & + \\
\hline SG-I & $5, \mathrm{I}$ & - & - & - & - & - & + & - & - & - & AAsHILLyMPTTrV & + \\
\hline SG-2 & 5 & - & - & - & - & - & + & - & - & - & AAsHILLyMPTTrV & + \\
\hline DAW-I & - & - & - & 5,1 & 5,1 & $5, \mathrm{I}$ & + & - & - & - & AAsHILLyMPTTrV & + \\
\hline DAW-2 & 5 & - & - & - & - & - & + & - & - & - & AAsHILLyMPTTrV & + \\
\hline DUB-2 & - & - & - & - & - & - & + & - & - & - & AAsHILLyMPTTrV & + \\
\hline DUB-3 & I & - & - & - & - & - & + & - & - & - & AAsHILLyMPTTrV & + \\
\hline $\mathrm{A}-2$ & - & - & - & - & - & - & + & -- & - & - & AAsHILLyMPTTrV & + \\
\hline A-3 & I & - & - & - & - & - & + & - & - & - & AAsHILLyMPTTrV & + \\
\hline JL-I & $\mathbf{I}$ & - & - & - & - & - & + & - & - & - & AAsHILLyMPTTrV & + \\
\hline
\end{tabular}


Tables $6 a, b, c$. Herpetosiphon species: experimental data for all strains

For explanations of columns I-26, see p. I6I.

Table $6 a$.

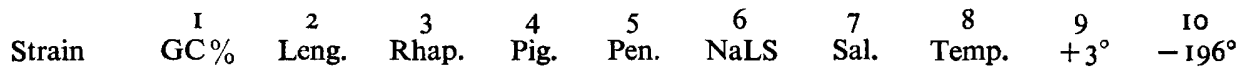
Herpetosiphon cohaerens

$\begin{array}{llllllllll}\begin{array}{l}\text { Herpetosiphon cohaerens } \\ \text { II-2 }\end{array} & 44 & >50 & - & 3 & 8 & - & \frac{1}{2}-2 \mathrm{~S} & 30 & + \\ \begin{array}{l}\text { H.persicus } \\ \text { T-3 }\end{array} & 52 \cdot 5 & >50 & - & 3 & 6 & - & \frac{1}{2}-2 \mathrm{~S} & 30 & + \\ \begin{array}{l}\text { H. nigricans } \\ \text { SS-2 }\end{array} & 53 & >50 & - & 4 & 6 & - & \frac{1}{2}-2 \mathrm{~S} & 35 & \end{array}$

Table $6 b$.

$\begin{array}{lccccccccccc} & \text { II } & \text { I2 } & \text { I3 } & \text { I4 } & \text { I5 } & 16 & 17 & 18 & 19 & 20 & 2 \mathrm{I} \\ \text { Strain } & \text { CMC } & \text { Star. } & \text { Agar } & \text { Algin } & \text { Gel. } & \text { Lit-Mil. } & \text { Cat. } & \mathrm{H}_{2} \mathrm{~S} & \text { Tyr. } & \text { DOPA } & \text { Nit. }\end{array}$ Herpetosiphon cohaerens

II-2 $\quad-\quad-\quad-\quad-\quad+\quad+\quad+C R$

H. persicus

T-3

H. nigricans

SS-2

Table $6 c$.

22

23

$24 \quad 25 \quad 26$

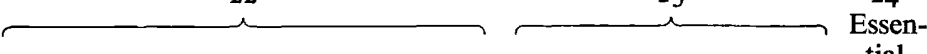

tial

Strain Ace. Lac. Gly. Glu. Gal. Suc. Tryp. CAA Glut. $\mathrm{NO}_{3}{ }^{-}$AAs Vit. Nuc Herpetosiphon cohaerens

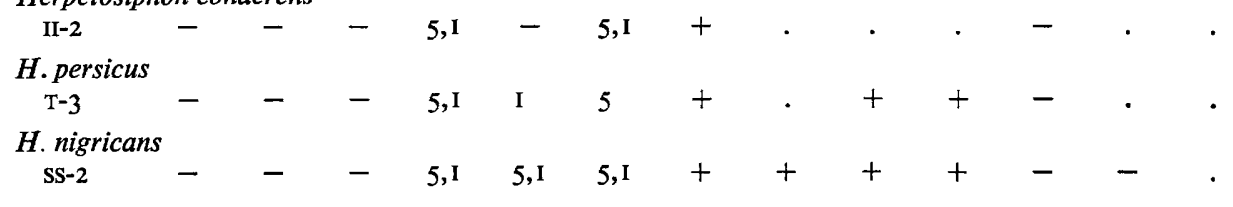

Table 7. Pigment types of flexibacteria

\begin{tabular}{|c|c|c|c|c|c|}
\hline $\begin{array}{l}\text { Pigment } \\
\text { type }\end{array}$ & $\begin{array}{l}\text { Colour } \\
\text { of cells }\end{array}$ & $\begin{array}{c}\text { Example } \\
\text { (species* and strain) }\end{array}$ & $\begin{array}{c}\text { Absorption } \\
\text { maxima of } \\
\text { crude extract in } \\
n \text {-hexane (nm.) }\end{array}$ & $\begin{array}{c}\text { Main } \\
\text { pigment(s) }\end{array}$ & $\begin{array}{l}\text { Ref. (Aasen } \\
\text { \& Jensen) }\end{array}$ \\
\hline I & Red & $\begin{array}{l}\text { Flexibacter roseolus } \\
\quad \text { (CR-I4I) }\end{array}$ & $450,475,505$ & $\begin{array}{l}\text { Flexixanthin and } \\
\text { deoxyflexixanthin }\end{array}$ & I966b \\
\hline II & Pink & $\begin{array}{l}\text { Saprospira thermalis } \\
\text { (BEG) }\end{array}$ & $450,47^{8,}, 505$ & 'S.t. 483' & I966c \\
\hline III & Orange & S. grandis $(\mathrm{WH})$ & $\begin{array}{c}425,447,471 \\
505 \dagger\end{array}$ & Saproxanthin & I966a \\
\hline III $a$ & Or.-yell. & S. toviformis (A-I) & $\begin{array}{c}425,447,47 I \\
505 \neq\end{array}$ & $?$ & - \\
\hline IV & Yellow & $\begin{array}{l}\text { Flexithrix dorotheae } \\
\quad(\mathrm{QQ}-3)\end{array}$ & $425,45^{\circ}, 478$ & Zeaxanthin & I966c \\
\hline V & Yellow & F. aurantiacus (DWo) & $423,453,480$ & $?$ & - \\
\hline VI & Red & $\begin{array}{l}\text { Cytophaga latercula } \\
\text { (SIO-I) }\end{array}$ & $440,465,488$ & $?$ & - \\
\hline
\end{tabular}

